University of Rhode Island

DigitalCommons@URI

Open Access Master's Theses

1981

\title{
The Establishment of Conditioned Reinforcement in Rats: Information Value or Contiguity
}

Robert Stephen Harris

University of Rhode Island

Follow this and additional works at: https://digitalcommons.uri.edu/theses

\section{Recommended Citation}

Harris, Robert Stephen, "The Establishment of Conditioned Reinforcement in Rats: Information Value or Contiguity" (1981). Open Access Master's Theses. Paper 1613.

https://digitalcommons.uri.edu/theses/1613

This Thesis is brought to you for free and open access by DigitalCommons@URI. It has been accepted for inclusion in Open Access Master's Theses by an authorized administrator of DigitalCommons@URI. For more information, please contact digitalcommons-group@uri.edu. 


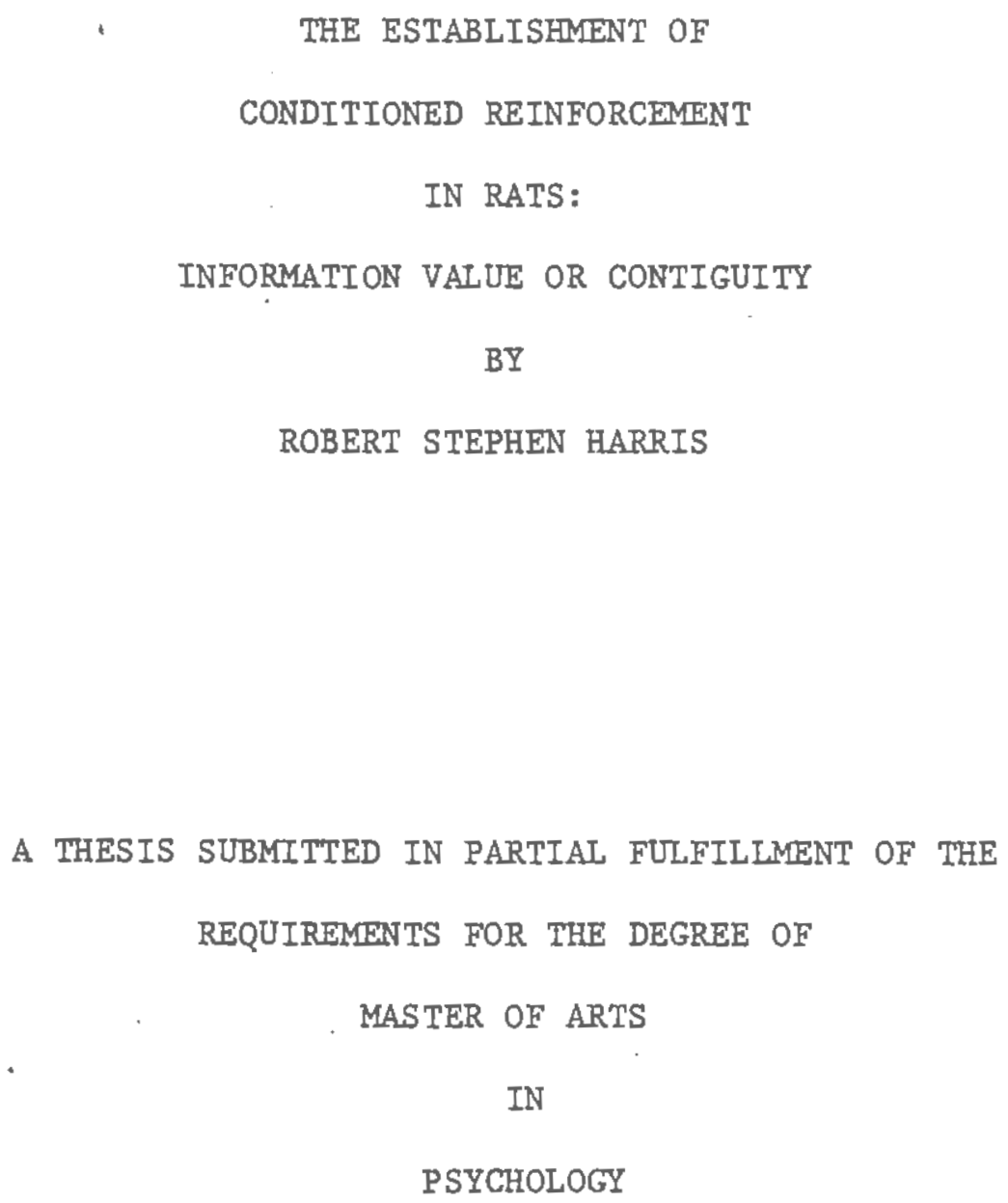

A THESIS SUBMITTED IN PARTIAL FULFILIMENT OF THE REQUIREMENTS FOR THE DEGREE OF MASTER OF ARTS

IN

PSYCHOLOGY 


\section{ABSTRACT}

An experiment was performed to determine the relative efficacy of "predictive information value" and of temporal contiguity with a primary reinforcer $\left(S^{R}\right)$. In establishing conditioned reinforcement value of previously neutral stimuli. Three different temporal patterns of pairs of neutral stimuli were presented both contiguously with non-response contingent primary reinforcement (experimental groups) and non-contiguously with primary reinforcement. Subsequently, the efficacy of these stimuli in reinforcing a new respense (lever press) was assessed, both across pairs of stimuIi and within each pair. Previous findings regarding the optimal temporal intervais between stimuli and between stimuli and reinforcement for maximum information value and maximum contiguity were utilized to allow discrimination between the predictions of the two models. Forty-eight Sprague-Dawley adult male rats were trained with 210 non-contingent presentations of the neutral stimuli and the $s^{R}$ over a period of five days. For half of the subjects, the stimuli and SR were presented contiguously. The other half received the stimuli at random. Relative to presentation of the $S^{R}$, using a random control procedure.

Subjects were tested over a three day period in a two lever operant chamber with the neuțral stimuli avaflable on separate levers 
contingent upon the lever press response. Daily testing trials lasted 30 minutes with each daily session being recorded in consecutive 5 minute segments.

The results were analyzed using two four-way ANOVA's with repeated measures across two factors, the first being number of responses across successive days of testing and the second number of responses across successive 5 minute segments of Day 1 . In the first ANOVA, a significant main effect was indicated across daily testing sessions. A follow-up test indicated that responding occurred primarily during Day 1, with negligible responding during Days 2 and 3 . No other significant main effects or Interaction effects were found in the first analysis.

In the second ANOVA, a significant main effect was found for consecutive 5-minute testing segments, as well as a significant interaction between the experimental/control factor and the repeated measures $S_{1} / S_{2}$ factor. Follow-up tests indicated that greater responding occurred during the first two 5-minute segments and that control subjects responded more to the first stimulus than did experimental subjects. Further, experimental subjects in one stimulus pair showed a preference for $S_{2}$, while controls showed a preference for $S_{1}$. These results occurred, however, in the stimulus pair predicted to have the least optimal temporal arrangement for the establishment of a conditioned reinforcement effect.

Overall, the results did not provide adequate support for either a contiguity or information model. Possible problems of insensitivity 
in the procedure with this traditionally weak phenomenon are discussed as well as the possibility that the true conditloned reinforcer may have been the pattern of both stimuli whlch was not presented in testing. Further research possibilities are discussed. 


\section{ACKNOWLEDGEMENTS}

I would like to express my sincere gratitude to several people who have assisted me in the completion of this research. Special thanks are extended to \&aul Gallagher, without whose equal sharing of responsibility in constructing the experimental apparatus and running the subjects, I would no doubt still be gathering data. His conscientiousness and thoughtful suggestlons well surpassed expectations of a fellow experimenter.

I would also like to thank Dr. Albert Silverstein, my major professor, for his assistance in the design and completion and this research. Further appreciation is extended to the remaining members of my comittee--Dr. Nelson Smith, Dr. Wayne Velicer, Dr. James Prochaska, and Dr. James Loy--for their critically helpful suggestions.

Appreciation is also extended to William $2 w i c k$ and Pamela Zappardino-Harris for their assistance with problems presented by the data analysis. 


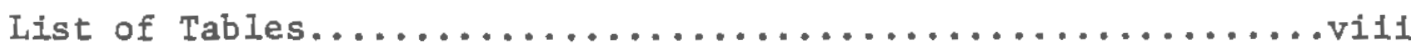

List of Figures............................. ix

Introduction. .............................. I

Method

subjects................................ 22

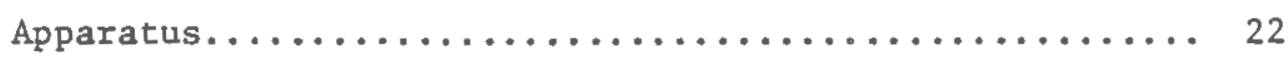

Procedure............................... 22

Results.................................. 34

Discussion................................. 49

References................................ 56

AppendIx A.

Means and Standard Deviations for Number of Lever

Presses During Testing...................... 61

Appendix B.

Means and Standard Deviations of Log Transformed Scale

For Number of Lever Presses Durfing Testing........... 64

Appendix C.

Newman-Keuls Test of Days 1, 2 and 3 Across

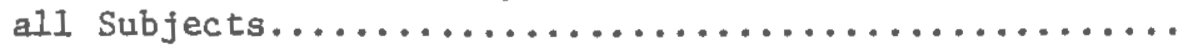

Append1x D.

Means and Standard Deviations for Number of Lever

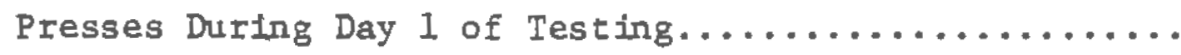

Appendix E.

Means and Standard Deviations of Log Transformed Scale For Number of Lever Presses During Day I of Testing..... 74 
Appendix F.

Newman-Keuls Test of Segments $1,2,3$ and 4

Across all subjects....................... 80

Appendix G.

Simple Main Effects Tests of B (treatment) at C

(stimulus) Across all Subjects for Segments I, 2,

3 and 4 of Day $I$ of Testing.................. 81

Appendix H.

Simple Main Effects Tests of C (stimulus) at B

(treatment) Across all Subjects for Segments 1 ,

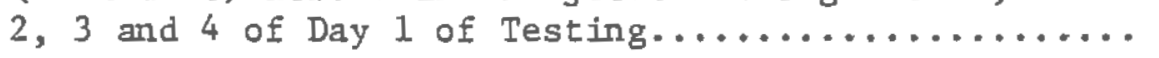

Appendix I.

Simple, Simple Main Effects Tests of C (stimulus) at $A B$ (configuration $x$ treatment) for Segments $1,2,3$

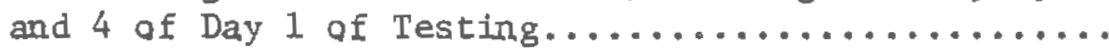

Appendix J.

Simple Main Effects Tests of B (treatment) at A2

(14 sec-I3 sec) for Segments $1,2,3$ and 4 of

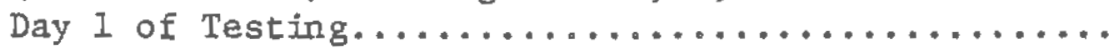

84 


\section{LIST OF TABLES}

TABLE

PAGE

1. Analysis of Variance Sumary Table................ 36

2. Analysis of Variance Sumary Table................. 38

3. Means and Standard Deviations for Number of Lever Presses Collapsed Across all Factors for Segments $1,2,3$ and 4 of Day 1 of Testing................ 40

4. BC Summary Table.......................... 46

5. AB Summary Table: ABC Summary Table................ 47 


\section{IIST OF FIGURES}

FIGURES

PAGE

1. Diagram of stimulus configurations during the training phase of Egger and Miller's

experiment $(1 "=1$ second) ......................... 12

2. Diagram of stimulus configurations for

Experimental Group I and Control Group I

$\left(1^{\prime \prime}=1\right.$ second $) . \ldots \ldots \ldots \ldots \ldots \ldots \ldots \ldots \ldots$

3. Diagram of stimulus configuration for ExperimentaI Group II and Control Group II

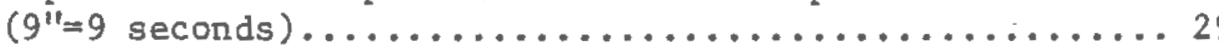

4. Diagram of stimulus configuration's for ExperimentaI Group III and Control Group III

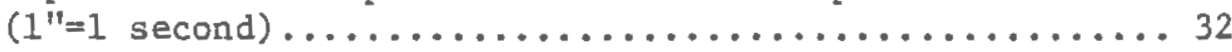

5. Graph of BC (treatment x stimulus) interaction at levels of $B$ (treatment) ..................442

6. Graph of $B C$ (treatment $x$ stimulus) interaction

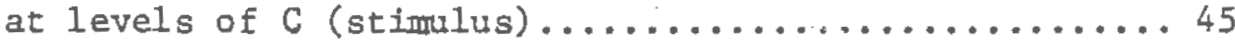


THE ESTABLISHMENT OF CONDITIONED REINFORCEMENT IN RATS: INFORMATION VALUE OR CONTIGUITY

Few concepts have received as much attention as explanatory mechanisms within the field of learning as has that of conditioned or secondary reinforcement. Some stimuli appear to be, by their inherent nature, reinforcing and will in the absence of any prior experience increase the subsequent frequency of responses which they follow, Other stimuli seem to have little, if any, effect on behavior at the outset of their occurrence. Yet after a sufficient period of certain types of exposure, these stinuli seen to acquire the ability to affect behavior in ways similar to those stimuli requiring no prior experience. Those stimuli requiring some amount of exposure are referred to as conditioned or secondary reinforcers $\left(S^{r}\right)$ while their counterparts are termed primary reinforcers $\left(S^{R}\right)$.

Very little human behavior is under the direct control of primary reinforcers such as food or water. On the contrary, human behavior seems very greatly affected by such tangible stimuli as money and material possessions and intangibles in the form of praise, attention, and success. These stimuli are often assumed by learning theorists to be categorized under the heading of conditioned reinforcers. It is not surprising, therefore, that a large body of experimental and applied Iiterature has been devoted to attempts to understand and explain the necessary and sufficient conditions by which conditioned reinforcers 
are established and maintained.

Three major experimental paradigms have evolved in an effort to understand this function. The first approach hlstorically is the extinction method (Bugelski, 1938). Subjects are trafned on some instrumental task, either a discrete trlal task or a free operant task, which is followed by a "neutral stimulus" paired with a primary reinforcer. A test phase is then introduced in which the previous task is no longer followed by primary reinforcement but continues to be followed by the previously neutral stimulus. After repeated pairing of the neutral stimulus (e.g., bell, click, tone, light, etc.) with the primary refnforcer, the formerly neutral stimulus is said to have become a condtioned reinforcer, provided the subsequent test phase yields results in the approprlate direction. A significant decrease in the rate of extinction from that of a control condition is interpreted as a positive conditioned reinforcement effect.

This paradign has been criticized because of the fact that results originally attributable to conditioned reinforcement effects seem to be amenable to several equally plausible altemative explanations (Wike, 1966). While differential effects between experimental and control groups may be attributable to the previously neutral stimulus functioning as a conditioned reinforcer, it is also possible that effects are due to lesser stimulus generalization decrement within the experimental group (Wike, 1966) or greater arousal of general activity levels (Gilbert \& Sturdivant, 1958) within experinental groups. Because of the inability of the paradigm to control for these altemative 
explanations, this design has largely ceased to be employed.

A second approach incorporates a variety of procedures, the most frequently used of which are token designs and chained schedules (Wike, 1966; Kelleher \& Gollub, 1962). These procedures may be referred to as maintenance tests, because of the fact that primary Ieinforcement remains available in the test phase. In token studies, for example, subjects are typically trained to use poker chips in some manner (e.g., to insert them into a vending machine (Wolfe, 1936)) to obtain primary reinforcement. A delay is then instituted in which subjects are required to accumulate tokens before exchanging them. Finally, in the test phase, subjects are required to perform a task in order to obtain the tokens as a means of assessing the conditioned reinforcing effectiveness of the tokens. Whereas in the extinction paradigm primary reinforcement was no longer ava1lable subsequent to the training phase, in the latter studies tokens earned during the test phase are exchangeable for primary reinforcement on either an immediate or delayed schedule.

In the chained schedule, subjects are required to perform in one component of a chain in order to obtain a stimulus (discriminative stimulus; $S^{D} ; S_{I}$ ) under which appropriate responding will yield primary reinforcement. Responding in the first component of the chain is said to be attributable to the $s^{T}$ functions of the $s^{D}$ for the second component. Chained schedules may be homogeneous, i.e., they may involve the same response in different components of the chain, or heterogeneous, i.e., they may involve two or more different responses, one for each component of the chain. Proponents of the chained schedule 
interpret token studies as examples of heterogeneous chains in which the last response in the chain is an exchange response (Kelleher \& Gollub, 1962).

The major drawback of the paradigm stems from the confounding of both $S^{D}$ and $S^{r}$ functions within the stimulus of interest. For example, assume that a pigeon is key pecking on a FI 2-minute schedule in the presence of a red light. The termination of the first segment of the chain is signaled by the offset of the red 1 ight and the onset of a green light signalling that an FI 5-minute schedule is in effect, at the end of which the green light offsets and primary reinforcement is delivered. Proponents of chained procedures would regard the green light as the Sr maintaining responding in the first segment of the chain. However, it is impossible to examine the necessary and sufficient conditions for the establishment and maintenance of $s^{r}$ effects at the same time a stimulus is functioning as $s^{D}$ for responding in the subsequent segment. The use of a tandem chain in which neutral stimuli are omitted effectively controls for the effect of the stimulus in the chain. However, by removing the stimulus, discriminative stimulus and conditioned relnforcer effects are simultaneously removed. In addition, the continued presence of the SR at the end of the chain confounds the interpretation of an Sr effect. The third paradigm is that of the new learning test (Wike, 1966). The training phase of this design may be identical to that of an extinction paradigm. The subject may be trained to perform a task which is followed by a neutral stimulus and a primary reinforcer or, on the 
other hand, the stimulus complex (the neutral stimulus followed by the primary reinforcer) may be delivered non-contingently, 1.e., the subject is fed on cue rather than contingent upon the performance of an operant. The unique feature of this paradigm, however, is that the anfmal is now given the opportunity to perform a task different from any he learned in the first phase of the experiment. The new task is followed by the previously neutral stimulus. Evidence of an increase in performance of the new task relative to an appropriate control is taken as support for conditioned reinforcenent.

While this latter paradigm provides the least confounded test of $\mathrm{S}^{\mathrm{x}}$ effects, a major drawback is nevertheless inherent, since the test phase proceds in the absence of primary reinforcement. Thus, $s^{r}$ strength, which is at best moderate at the outset, is continually weaken fng.

Perhaps the most striking problem that may be noted in a review of the literature, however, stems not from the paradigm chosen to examine the phenomenon, but rather from the lack of adequate attention to experimental controls across all paradigms. Bolles (1967) states that:

There is probably no concept in a11 of psychology that is in such a state of disarray as the concept of secondary reinforcement (p. 368).

This "disarray" is attributable in large part to inattention to critical control issues. To this end, Wike (1966) devotes one chapter exclustvely to a discussion of control procedures.

Among the control issues which are most critical are comparisons 
which address the issue of altemative explanations of $s^{r}$ effects (such as stimulus generalization decrement) and various alternative theoretical interpretations of the $S^{r}$ phenomenon.

As a result of problems in identifying the most appropriate paradigm, and developing adequate controls to elfminate altemate explanations of experinental effects, little progress has been made in answering even the most basic questions regarding the conditioned reinforcement phenomenon. Consequently, we are left still asking the question, "What are the necessary and sufficient conditions for the establishment of conditioned reinforcer effects?"

Several theories have been developed with varying degrees of support. Skinner (1938) states that a stimulus may become a conditioned rejuforcer if it functions as a discriminative stimulus. Keller and Schaenfeld (1950) have gone further to state that the establishment of a stimulus as an $S^{D}$ is a necessary and sufficient condition for its becoming a conditioned reinforcer. Several studles bear favorably on this hypothesis, generally referred to as the discriminative stimulus hypothesis. Studies by Schoenfeld, Antonltis, and Bersh (1951) and Dinsmoor (1957) are typlcally cited within this context. It must be remembered, however, that these studies address only the 1ssue of whether $1 t$ is sufficient to establish a stimulus as an $s^{D}$ in order for it to function as an $\mathrm{S}^{\mathrm{r}}$. It would appear from their results that this is in fact the case. While Schoenfeld, et al. compare their SD group with a group in which, the neutral stimulus was temporally contiguous with food delfvery, It is not clear that subjects in this latter group 
discriminated the neutral stimulus. Therefore, the question, as to whether it is necessary for a stimulus to function as an SD in order for it to function as an $\mathrm{Sr}$, has not been adequately addressed.

While several studies (Rataer, 1956; Ferster, 1953; Autor, 1969) might be offered as negative support for the latter, perhaps the first serious challenge to the discriminative stimulus hypothes is was the work of Stein (1958) with respect to the establishment of $S^{r} s$ ia electrical stimulation of the brain. Stein placed subjects in a two lever chamber and followed presses on one lever consistently with a tone (Phase I). No preferences were indicated for either lever. During the second phase of the experiment (Phase II), subjects were delivered paired presentations of the tone and electrical stimulation to the brain (ESB) in the absence of the levers. Tone onset preceded ESB by $0.5 \mathrm{sec}$. and terminated simultaneously with ESB offset after one second of tone presentation. Phase one conditions were then reinstated as a test of the newly acquired $S^{x}$ effects of the tone (Phase III). Finally in the last phase of the experiment (Phase IV) ESB was made contingent upon the performance of the lever press response. The latter was a test of the prinary reinforcer effects of ESB sites. Comparisons were made between Phase I and Phase III for those subjects who demonstrated SR effects in Phase IV. Preferences for the tonecontingent lever as well as increases in response rates were evident. Some concern may be raised regarding Stein's procedure due to the lack of adequate attention to controls. Subjects not responding to the SR in the post-test phase (employed to assess SR effects) were employed 
as controls for the physiological procedure. No controls appropriate to the $\mathrm{Sr}$ component of the procedure were employed e.g., rand om presentation of the tone relative to ESB in training followed by contingent presentation of the tone during testing.

However, while not well controlled, Stein's study does suggest the existence of conditioned reinforcer effects in the absence of discriminative stimulus functions. The tone did not precede or signal an operant or known respondent nor was any likely to have developed accidentally during the 0.5 second inter-stimulus interval (ISI). While the occurrence of responses during similar intervals has been observed (Pliskoff, Hawkins, \& Wright, 1964) the phenomenon is somewhat rare and as such Improbable (Kling \& Schrier, 1972).

A second study by Crowder et al. (1972) provides additional difficulty for the SD theory of Sr. Using a model similar to Stein's, Crowder et a1. placed animals in a single lever operant chamber for a 5 hour pre-training period, for the purpose of establishing baseline. Each response was followed by the presentation of a buzzer together with an infusion of $0.018 \mathrm{ml}$ of saline. At the end of the 5 hour baseline period the bar was removed and subjects were presented non-contingently with 100 buzzer-morphine palrings.

Testing followed the next day, beginning at the same time as the original operant period. With the lever once again in the chamber, subjects were again dellvered buzzer-saline pairs contingent upon barpressing. Animals were then given a second 5 hour test 
period in which buzzer-morphine pairings were delivered contingent upon leverpressing. The latter session was used to delete subjects not responding to the morphine as an SR. Three groups of subjects, each receiving different doses of morphine, were used.

A significant increase in responding above baseline operant levels was found as well as a significant effect of magnitude of morphine. Like Stein's study, no $S^{r}$ controls were used, therefore rendering the results somewhat inconclusive. However, a withinsubjects effect comparable to that obtained by Stein was Identified. In addition, attending to the criticism of Stein's work by Pliskoff et al., subjects in the Crowder et al. study were closely observed for the development of superstitious behavior in the presence of $S^{+} / S^{R}$ pairings during training. No stereotyped behavior was observed.

In summary, it may be concluded that discriminative stimuli are often conditioned reinforcers, but the evidence also indicates that stimuli may acquire $S^{r}$ properties by simple pairing with primary reinforcement. It is not necessary to establish a stimulus as an ${ }_{0} \mathrm{D}$, 
refnforcer. If such were the case, "primary" or " $s$ " rather than "S" ${ }^{r}$ would seem to be the more appropriate designation. Given then that cont1guity is necessary, is $1 t$ suffictent?

The work of Stein, as well as that of Crowder et al., would seem to indicate an answer in the affirmative. Egger and Miller (1962), however, have proposed that simple pairing is not sufflcient. According to their information hypothesis, a stimulus must provide some information about the forthcoming $s^{R}$. An informative stimulus, i.e., one which precedes the delivery of a primary reinforcer and thereby predicts 1 ts occurrence (see $S_{1}$ in Condtion A of Figure 1), w111 acquire $S^{r}$ Strength, while a redundant stimulus, 1.e., one which

Ineert Figure 1 about here

occurs subsequent to the onset of the first or informative stimulus but prior to the delivery of $\mathrm{S}^{\mathrm{R}}$ (see $\mathrm{S}_{2}$ in Condition $\mathrm{A}$ of Figure 1 ), thereby according to Egger and Miller, provldes no new Information which would enhance the predictabllity of $s^{R} s$ occurrence and thus would not acquire $S^{r}$ strength. The same may be said for a reliable stimulus, 1.e., one which consistently occurs inmediately prior to the onset of $\mathrm{s}^{\mathrm{R}}$ (see $\mathrm{S}_{2}$ in Condition $\mathrm{B}$ of Figure 1 ) will acquire $\mathrm{s}^{\mathrm{r}}$ strength, in contrast to an unreliable one, which occars immediately prtor to the onset of $S^{R}$ but also occurs at other times unrelated to the delivery of $s^{R}$ (see $S_{1}$ in Condition $B$ of Figure 1 ).

Consider the stimulus configurations employed by Egger and 
Figure 1. Schematic diagram of stimulus configuration during the training phase of Egger and Miller's experiment ( $1^{\prime \prime}=1$ second). Condition A represents the experimental training configuration in which Stimulus 1 provides new reliable non-redundant information regarding the SR and Stimulus 2 redundant; Condition B represents the experimental trainfng configuration in which Stimulus 2 is reliable, though redundant, and Stimulus 1 is unreliable (sometimes occurs in isolation). 
Experimental

Training

Condition A:

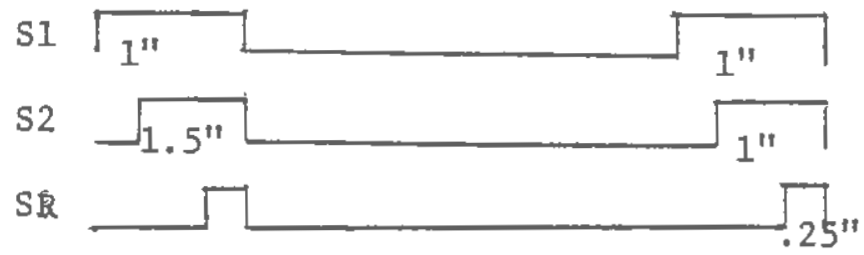

Experimental

Training

Condition B:

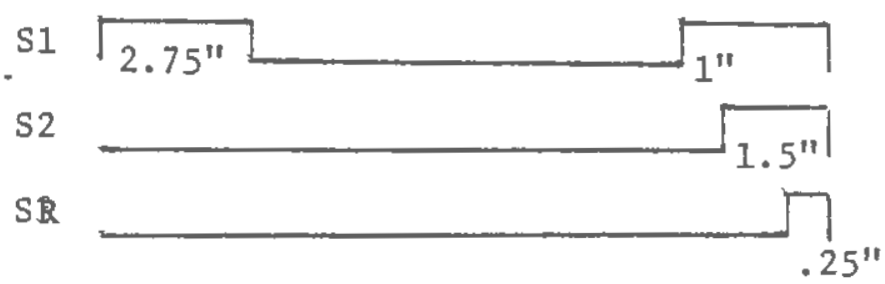

\footnotetext{
S1 - Neutral stimulus (tone or flashing light)

S2 - Neutral stimulus (tone or flashing light)

SR - Prinary reinforcer (food pellet)
}

FIgure 1 
Mfller (see Figure 1). In condition $A, S_{2}$ is redundant. $S_{1}$ reliably predicts the occurrence of $S^{R}$ and is presented prior to and simultaneously with $\mathrm{S}_{2}$ in an overlapping configuration. According to the information hypothesis proposed by Egger and Miller; $\mathrm{S}_{1}$ should function as the superior reinforcer.

In condition $\mathrm{B}$, however, $\mathrm{S}_{2}$ more reliably predicts the occurrence of $\mathrm{S}^{\mathrm{R}}$ and is only redundant with alternate occurrences of $\mathrm{S}_{1} \cdot \mathrm{S}_{2}$ can therefore be sald to have greater informative value, and should function as the more effective reinforcer. Egger and Miller went on to say that $\mathrm{S}_{2}$ in condition $A$, even though it has a more favorable position, in terms of a gradient of delay, will acquire little or no Sr value. While either of the former statements are compatible with a simple pairing approach, it is.the latter that defines simple pairing as insufficient.

Egger and Mfller's procedure involved the following phases: (1) subjects trained to barpress for food, (2) bar removed, and in the same box, S1 and S2 presented with food, (3) subjects retrafned to barpress for food, (4) subjects extinguished, (5) subjects retrained to barpress for S1 or S2.

Egger and Miller's procedure employed three types of controls. One group of subjects, an "activation" control group, was trained using a yoked procedure in which stimuli were delivered contingent upon barpressing by the experimental subject to which each control subject was yoked. For these subjects, the bar was non-functional and barpressing was interpreted as an indfcation of the extent to 
which the prevlously neutral stimuli "activated" barpressing.

Egger and Miller also employed a pseudoconditioned and unconditioned control group. Subjects in the pseudoconditioned group received the neutral stimuli in an explicitly unpaired procedure 1.e., the neutral stimulus pair was presented randomiy with the constraint that its presentation overlap at no point with the primary reinforcer. Unconditioned subjects received no food pellets at all during tra1ning. While these control procedures were substantially superfor to those used in the typical Sr study, the most critical group, that group subjected to the pseudocond1tioning procedure, was conceivably aversively conditioned to the neutral stimuli, (Rescorla, 1967) by virtue of the stimuli, SI and S2, being explicltly falred with the absence of SR. Between group differences could therefore be attributed to the aversive conditioning of the control subjects rather than appetitive conditioning of the experimental subjects. In addition, it should be noted that control comparisons were tested separately from the overall analysis, therefore, increasing the likelihood of Type I error.

Despite these criticisms, however, 1t must be noted that Egger and M11ler found, using a whin subjects comparison, that responding to $\mathrm{S} 1$ was significantly greater than responding to $S 2(p<.001)$.

The information hypothesis is not incompatible with a discriminative stimulus approach. As Hendry (1969) points out, the establishment of any discrimination generates informative stimuli. Hendry has 
expanded upon the discrimfnative stimulus hypothesis and Egger and Miller's proposal with a more elaborate conceptualization of the information hypothesis. According to Hendry the essential role of an $\mathrm{Sr}$ is to reduce uncertainty regarding the subsequent occurrence of reinforcement or the performance of an operant. This is accomplished In two ways subsumed under two separate but related hypotheses.

The "clue hypothesis", as it is designated by Hendry, is similar to that of Egger and Miller, in which the essentlal function of the $\mathrm{Sr}$ is to provide the subject with clues signifying what subsequent stimuli to expect, i.e., to reliably predict the subsequent occurrence of established reinforcers. This approach is essentially a cognitive refinement and extension of a contiguity approach.

On the other hand, the "cue hypothesis", as it is identified by Hendry, states that the essential role of the $\mathrm{Sr}$ is to signal the subject as to what to do, i.e., to govern the ratio of the performance of an operant. This latter hypothesis requires a response contingent training procedure in order to establish the Sr's cue function.

According to Hendry, simple pairing and $S^{D}$ training are insufficlent for the establishment of an $S^{r}$. In order to function as an $S^{r}$, a stimulus must provide additional information. In support Hendry cites two predictions. First, stimuli associated with multiple schedules will function as $s^{r}$ s so long as the multiple schedule remalns in effect. This prediction is made by both $S^{D}$ and 
cue hypotheses. Secandly, stimuli assoclated with identical multiple schedule components will not function as $S^{r} s$. This prediction would not evolve from an $S^{D}$ hypothesis as both stimuli are functioning as $S^{D} s$ for subsequent responding. The cue hypothesis, operating on the assumption that $s^{D} s$ must be informative with respect to differential responding in order to function as $\mathrm{S}^{\mathrm{r}} \mathrm{s}$, would make the latter prediction.

Wyckoff (1969) in his work with observing responses observed that discriminative stimuli functioned as conditioned reinforcers in establishing and maintaining an observing response upon which the discriminative cues were contingent. Eliminating the discriminative function of the two cues, a "positive" cue signaling that SR was available and a "negative" cue slgnaling that no SR was available, was found to reduce the rate of the observing response to a relatively Low value. Upon subsequent reversal of the original discriminative pattem, the observing response retumed to a relatively high stable rate. While Egger and Miller's work implies a contiguity or S-S model, as indicated, the establishment of an uncertainty-reducing stimulus (Sr) via the development of an operant discrimination, as demonstrated by Wyckoff, follows an S-R model.

In sumary, both the position outlined and supported by Egger and Miller (1962) and its extension by Fendry (1969), hypothesized that a stimulus must possess some informative value beyond simple contiguity and discriminative stimulus properties in order to function as an $S^{r}$. Before accepting such a posttion, several conflicting points 
of evidence must be considered.

Bower, McLean and Meacham (1966) used a concurrent schedule deslgn in which a multiple FI 10/40 schedule (i.e., discriminative cues were present for each FI pattern) of relnforcement was aval1able on a rlght-hand response key wIth a mixed FI 10/FI 40 schedule (1.e., no discriminative cues for differential intervals were present) of reinforcement on the left-hand key. FI 10 and FI 40 schedules were programmed to occur an equal number of times in random sequence. Subjects Indicated a preference for the multiple schedule key. As the multiple schedule provided more Information, via differential $S^{D} s$, regarding the avallability of reinforcement, it would appear from this preliminary finding that a reduction in uncertainty is relnforcing, thus lending support to an information interpretation of the $S^{r}$ phenomenon.

To further test this assumption, Bower et al. reduced uncertatnty in both schedules by programming the FI 10 and FI 40 components In a $20 \% / 80 \%$ balance respectively. Based on this reduction in uncertainty, the preference for the key assoclated with the multiple schedule should have had less informative value. The predicted result was that preference for the multiple key should be reduced. Such was not the case. A reduction in the uncertainty of the schedules did not reduce $\mathrm{S}^{\mathrm{T}}$ effects. This analysis, however, places the major emphasis on the differential FI schedules themselves as the primary factor affecting 
the reduction in uncertainty. Examining the nature of the discriminative stimuli from a more global perspective, however, requires attention to additional features in the sitmulus complex such as the color of the keys. A prediction based on a shift in uncertainty relative only to the extension of the ratio of schedule availability is confounded by the presence of these additional cues in the stimulus complex. Thus, Bower's findings are relatively inconclusive. Bersh's (1951) study of the effect of delay of reinforcement upon $\mathrm{S}^{\mathrm{r}}$ effects is also difficult to explain within an information hypothesis approach. Bersh delayed food presentation following light onset for 0 , $0.5,1,2,4$, and 10 seconds. The light remained on until 2 seconds after the delivery of the food. In a new learning test Bersh then trained subjects to barpress for the light. The fact that the light remained on throughout the delay interval would indicate from an informatIon hypothesis prediction that no differential effects should be found. In all cases, the light was the last non-redundant stimulus to occur before food presentation. In addition, it was reltable. Bersh, however, found differential $S^{r}$ strengths among delay periods with I second being optimal. These results are difficult to justify within an information hypothesis approach. Adequate pseudo-conditioning controls were absent, however.

Further, the information hypothesis cannot account for the effect of magnitude of reward on $\mathrm{S}^{\mathrm{T}}$ during training (Greene, 1953; D'Amato, 1955; Crowder at al., 1972). An informat1on approach would say that magnitude or primary reinforcement should not affect the reliability 
or informativeness of an $\mathrm{S}^{\Gamma}$. This statement is difficult to reconctle with Wike's summary principle $k_{2}$ :

2. The strength of a secondary reinforcing stimulus vartes directly with the amount of primary reinforcement (food) used during secondary reward training (Wike, 1966, p. 460).

Wike (1966) points out a final problem with the information approach with respect to his summary princlples $\$ 4$ and $\# 5$ which are as follows:

4. A stimulus which 1s palred with $100 \%$ of primary reinforcement in secondary relnforcement training, using the differential method, will have greater secondary reward value than a stimulus palred with partial primary relnforcement.

5. A stimulus wilich is paired with partlal primary reinforcement in secondary reinforcement training, using the absolute method wll have greater secondary reward value than a stimulus palred with $100 \%$ primary refnforcement.

As Wike indicated, the information hypothesis can account for principle \#4. This in fact is simflar to a within subject design using Egger and Miller"s condition B (see Figure I). Princ1ple $\$ 5$, on the other hand, is not as easily accounted for. Given equivalent training to two groups of subjects, the respective information values of partial and continuous pairing should be identical to princlple $\$ 4$, that is, the continuously palred stimulus should be a more reliable predictor: of $\mathrm{S}^{\mathrm{R}}$ than the partially palred stimulus, Assuming that Wike's principle \#5 is correct (and several studies, while not well-controlled, are offered in support of princlple \#5 (Wike, 1966, p. 429-430), perhaps are forced to conclude that the information hypothesis applies only in the case in which two distinctive stimuli are presented.

The information hypothests proposes a point of view not incompatible with a contiguity hypothesis or a discriminative stimulus hypo- 
thesis. Both paired stimull and $S^{D} s$ are informative with respect to the forthcoming occurrence of $s^{R}$. As with the discriminative stimulus hypothesis, the establishment of information value in a stimulus would seem sufficient to endow a stimulus with $S^{I}$ capacities. Likewise, it is not unreasonable to suppose that the more informative a stimulus is, generally, the more reinforcing it will be--at least in the case of the sequentially overlapping presentation of two differentially informative stimul1. However, to state that information value is necessary to the extent that a.stimulus will reinforce only if it provides non-redundant or discriminative information is not supported by the available evidence. The present study attempted to firmly establish an SR effect in a situation in which one can compare the relative efficacy of information value and contiguity as explanatory mechanisms. The study combines

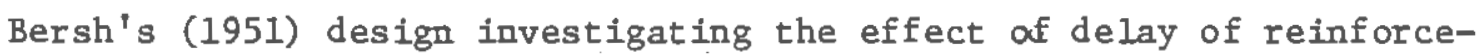
ment upon Sr effects together with Egger and Miller's (1962) procedure employing sequentially overlapping stimuli. However, in contrast to the prior studies, the present design employs a control group for each experfmental group. Each control was designed to permit the contrasting of contiguous pairing with random or non-contiguous presentation of the neutral stimuli and the SR: 1.e., each experimental group was assessed against its appropriate control.

Both Bersh and Egger and Miller employed training phases in which the reutral stimuli and the primary reinforcer were paired and delivered in the absence of response contingencies. In order to replicate this aspect of both studies, and at the same time, avoid possible contamination 
of the testing phase due to generalization effects of response contingent training, the present design employed non-response contingent training within a new learning paradigm. On the assumption that Egger and Miller's results are replicable, the following hypothesis and predictions are derived to allow for the limited generalizability of the information hypothesis while at the same time supporting the more general and more broadly applicable contiguity hypothesis. It is hypothesized that: The explanatory value of the information hypothesis of the establishment of conditioned reinforcement (as stated by Egger and Miller) is limited to the case wherein two optimally contiguous stimuli are presented in a sequentially overlapping manner. The contiguity hypothesis more parsimoniously accounts for $\mathrm{Sr}$ effects across the larger range of conditions identified for the establishment of said effects. The following predictions are derived from this hypothesis:

1. When two sequentially overlapping stimuli differ little in their optimal contiguity value, the first stimulus will acquire Sr strength. The second stimulus will acquire little if any $S^{r}$ value.

2. When the second of two sequentially overlapping stimuli is optimally contiguous and the first is not, the second stimulus will acquire $\mathrm{S}^{\mathrm{r}}$ strength. The first stimulus will acquire little if any $S r$ value.

3. When both. the two sequentially over lapping stimuli are not optimally contiguous, neither will develop Sr strength. 
METHOD

\section{Subjects}

Subjects were 48 experimentally naive adult male rats of the Sprague-Dawley strain, obtained from the Charles River Breeding Laboratories, whose mean weight at the outset of the study was 301.79 \pm 41.50 grams.

\section{Apparatus}

All subjects were trained and tested in a Colbourne Instruments Model E10-10 Modular Small Animal Test Cage (lever box), housed in a light-proof and sound-deadened environmental chamber constructed in the U.R.I. psychology department laboratory. The box was lighted continually by a 28 volt incandescent House Light and the pair of lights housed in a Colbourne Instruments Model E14-06 Liquid Dipper/ Pellet Food Cup. The house light was centered directly above the food cup and both house light and food cup were centered on one wall of the lever box. The apparatus was automated by solid state and electro-mechanical programining equipment.

\section{Procedure}

All subjects were water deprived to $80 \%$ of their ad libitum weight and malntained at that weight throughout training and testing phases. The training-testing sequence extended over eight consecutive days with Days 1 through 5 being devoted to training and Days 6 through 8 being used for testing. During the training phase, all 
subjects were placed in the lever box.

All subjects received $0.3 \mathrm{cc}$ of sucrose solution in the food cup at the outset of training on Day 1, $0.1 \mathrm{cc}$ on Days 2 and 3 , and no sucrose solution at the outset of Days 4 and 5 of the five day training period.

During the training phase, all subjects received 210 presentations of a pair of sequentially overlapping neutral stimuli (an 80 decibel, 6000 cps tone and a 15 watt incandescent flashing (6 flashes/ sec. light) and a 4 second dipper access to a $15 \%$ solution of sucrose and water. The sucrose/water solution was determined to be sufficient to motivate pilot animals, deprived to $80 \%$ of their ad libitum weight, to vigorously approach the food cup and engage in consunmatory responding. Using a range of $4 \%$ to $32 \%$ concentration of sucrose and water, Guttman (1953) found the sucrose mixture sufficient to serve as an $S R$ in the developinent of a new operant.

All subjects received 50 presentations of the stimuli on Day 1 of training and 40 presentations per day on Days 2 through 5.

All experimental subjects received "pairings" of the neutral stimuli overlapping with the sucrose solution at varied intervals over time, with intervals between paired stimulus presentations averaging 45 seconds (range, 15-75 seconds) for Days 1 and 2 of training and averaging 60 seconds (range, 15-105 seconds) for Days 3,4 , and 5 .

All control subjects recelved presentations of the neutral stimuli at variable intervals identical to that of the experimental 
subjects. Control subjects, however, received presentations of the sucrose solution at fixed intervals of 45 seconds for Days 1 and 2 and 60 seconds for Days 3, 4, and 5, following Rescorla's (1967) "truly random" procedure. While 1 t is possible to regard this procedure as a case of temporal conditioning, initially to 45 second intervals of time and subsequently to 60 second intervals, the more important aspect of these groups was that of the random relationship between the $S R$ and the neutral stimuli. The neutral stimuli in this configuration therefore bear no identifiable relationship to the $S R$, thereby virtually eliminating the establishment of an Sr effect within the stimulus pair.

No response was required of subjects during the training phase, i.e., presentation of the stimulus pair and sucrose solution was non response contingent.

Subjects were divided into three experimental groups, each with its corresponding control group for a total of six groups. Groups were divided according to the configuration of the neutral stiquli during training. Within experimental and control groups, the modality (tone versus light) was counterbalanced with respect to order of presentation.

Following the training format outlined above with respect to the varlable interval presentation of neutral stimuli and primary reinforcer, Experimental Group I most closely matched Egger and Miller's (1962) study, with Stimulus 1 onset followed one second later by the onset of Stimulus 2, followed one second later by the delivery of the 
sucrose solution, followed four seconds later by the simultaneous offset of S1 and S2 and the removal of the sucrose solution $\left(S_{1}=6\right.$ sec; $S_{2}=$ $5 \mathrm{sec} ; \mathrm{SR}=4 \mathrm{sec}$ ). As indicated earlier, the corresponding control group differed in that the presentation of the neutral stimuli bore no predictable temporal relation to the delivery of the sucrose solution. The relationship between the presentation of the neutral stimuli exact1y duplicated Experfmental Group I.

Figure 2 illustrates the configuration of both groups.

Insert Figure 2 about here

Subjects in Experimental Group II received $S_{1}$, followed one second later by $\mathrm{S}_{2}$, followed 9 seconds 1 ater by the delivery of the sucrose solution, followed four seconds later by the offset of $S_{1}$ and $S_{2}$ and the removal of the sucrose solution $\left(S_{1}=14 \mathrm{sec} ; S_{2}=13 \mathrm{sec} ; \mathrm{SR}=4 \mathrm{sec}\right)$.

Control Group II, 1ike Control Group I, matched the stimulus configuration of Experfmental Group II, with the exception of the random relationship between the $s_{1} / s_{2}$ pair and $s^{R}$. Figure 3 1llustrates the configuration of these groups.

Insert Figure 3 about here

Experimental Group III experienced the onset of $\mathrm{S}_{1}$, followed nine seconds later by the onset of $S_{2}$, followed one second later by the delivery of sucrose followed four seconds later by the offset of $\mathrm{s}_{1}$ and $S_{2}$ and the removal of sucrose $\left(S_{1}=14\right.$ sec; $\left.S_{2}=5 \mathrm{sec} ; S R=4 \mathrm{sec}\right)$. As with Control Groups I and II, the configuration of stimuli in Control Group 


\section{Figure Caption}

Figure 2. Diagram of stimulus confz.gurations for Experimental Group I and Control Group I ( $I^{\prime \prime}=1$ second). The experimental stimulus configuration (S1/S2/SR) is presented across a varlable time interval. The control stimulus configuration (S1/S2) is presented randomly with the SR being delivered on a fixed schedule thus allowing for infrequent S1S2SR overlap. 
Experimental Group I

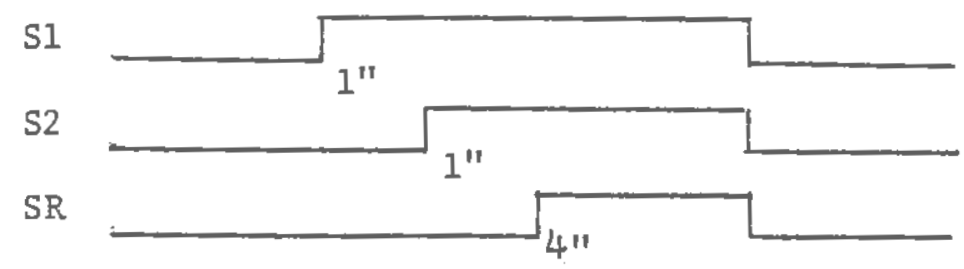

Control

Group I

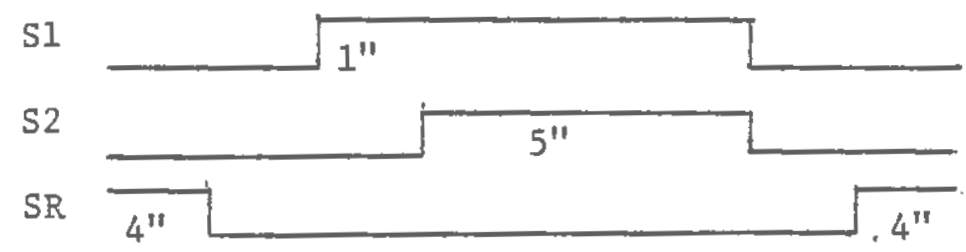

S1 - Neutral stimulus (6 second delivery of tone or flashing light)

S2 - Neutral stimulus (5 second delivery of flashing light or tone)

SR - Primary reinforcer (4 second delfvery of sucrose solution)

Figure 2 
Figure 3. Diagram of stimulus configurations for Experimental Group II and Control Group II ( $9^{\prime \prime}=9$ seconds). The experimental stimulus configuration ( 1 /S2/SR) is presented across a variable time interval. The control stimulus configuration (S1/S2) is presented randomly with the SR being delivered on a fixed schedule thus allowing for infrequent S1S2SR overlap. 
Experimental

Group II

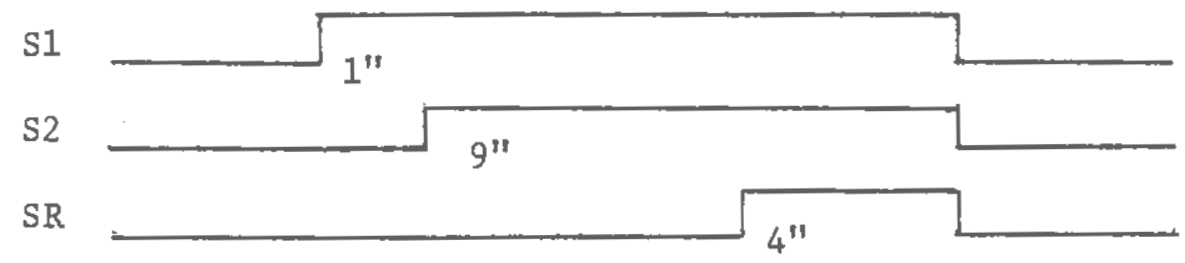

Control

Group

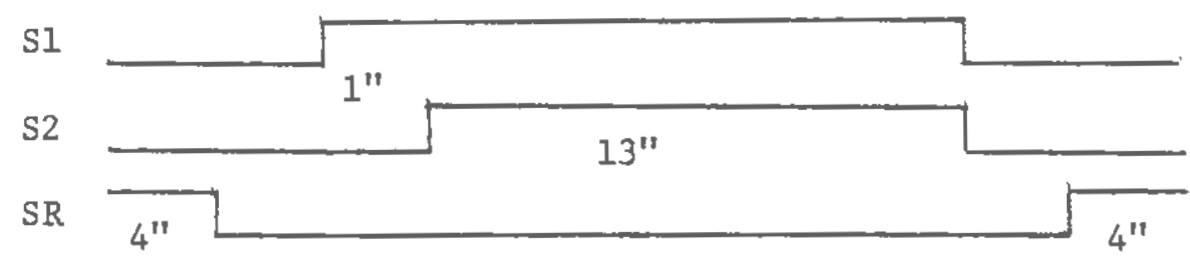

S1 - Neutral stimulus (14 second delfvery of tone or flashing 1ight)

S2 - Neutral stimilus (13 second delivery of filashing 1 ight or tone)

SR - Primary refnforcer (4 second delivery of sucrose solution)

Figure 3 . 
III matched that of Experimental Group III with the exception of the random relationship between the $S_{1} / S_{2}$ palr and $S^{R}$. Figure 4 illustrates the configuration of these last two groups.

Insert Figure 4 about here

Following the training phase, two levers were introduced into the experimental chamber, one on elther side of the food cup. Subjects were placed in the experimental chamber for one 30 minute session per day for three consecutive days (Days 6,7 , and 8 of the training/testIng sequence.) Each 30 minute session was divided into six consecutive 5 minute sessions for the purpose of recording responses. Responding on one lever resulted in the one second presentation of $S_{I}$ while responding on the other resulted in the one second presentation of $\mathrm{S}_{2}$. Stimuli were counterbalanced with respect to Ilght-left lever position. Once established, the right-left lever position remained fixed throughout testing. Number of presses served as the dependent measure.

While it is often the case that studies will measure baseline operant levels of the response(s) of interest, for the purpose of a within subjects comparison of baseline and test results, this study did not include such a component. The primary reason for this amission was to negate the possibility of extinguishing, during baseline, exploratory behavior necessary for inittal contact with the bar during testing, thereby attenuating, if not eliminating, any experimental affects. Additionally, it is important to note that because a within subjects preference procedure was used, any relationships obtained cannot be 


\section{Figure Caption}

Figure 4. Diagram of stimulus configurations for Experimental Group III and Control Group III (1" $=1$ second). The experimental stimulus configuration (S1S2SR) is presented across a variable time interval. The control stimulus configuration $(\mathrm{S1} / \mathrm{S} 2)$ is presented randomly with the SR being delivered on a fixed schedule thus allowing for infrequent S1S2SR overlap. 
32 .

Experimental

Group III

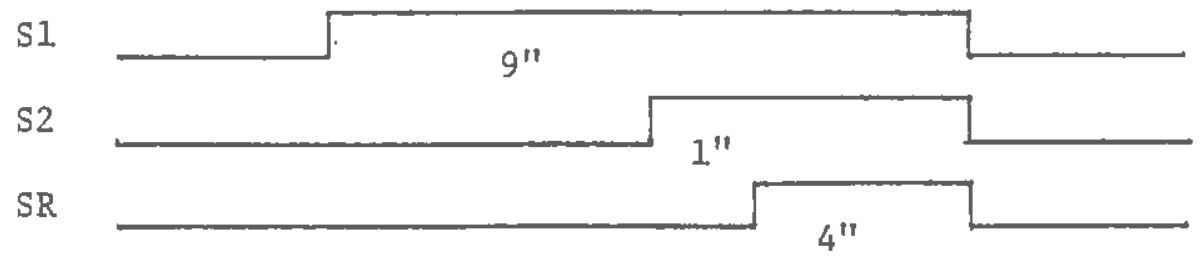

Control

Group III

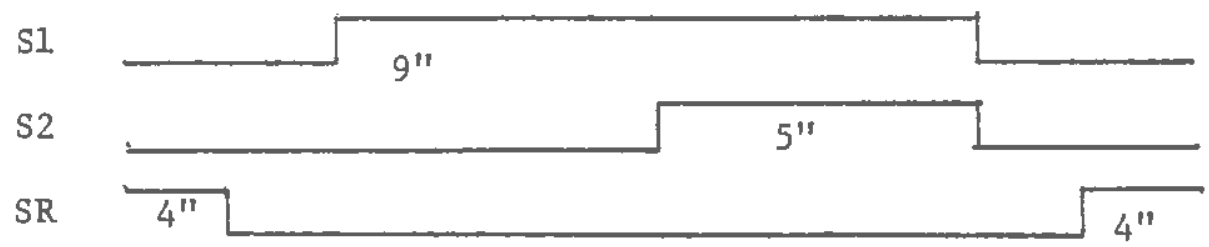

S1 - Neutral stimulus (14 second delivery of tone or flashing light)

S2 - Neutral stimulus (5 second delivery of flashing 11ght or tone)

SR - Primary reinforcer ( 4 second delivery of sucrose solution)

Figure 4. 
generalized to the between subjects case without explic1t verification in that kind of paradigm. 


\section{RESULTS}

A $3 \times 2 \times 2 \times 3$ ANOVA with repeated measures across the latter two factors was used to analyze the data across testing sessions. Factor A compared temporal arrangements of $S_{1}$ and $S_{2}$ (A, 6 sec., 5 sec.; $A_{2}, 14 \mathrm{sec} ., 13 \mathrm{sec} ; A_{3}, 14$ sec., 5 sec.). Factor $B$ compared experimental subjects receiving, in training, a presentation of the neutral stimul1 paired with the sucrose solution, with control subjects receiving the neutral stimuli in a random relationship to the sucrose solution. Factor $C$, the first of the repeated measures factors, compared responding to recelve $S_{1}$ during testing with responding to receive $\mathrm{S}_{2}$. Factor $\mathrm{D}$, compared mean responses across the three daily testing sessions.

Frequency of lever pressing was used as the dependent measure. (Means and standard devlations of this measure are represented in Appendix A.) Because of a significant violation of the assumption of homogeneity of variance $\left(F_{\max }(6,14)=113.54, p<.05\right)$, the data was transformed using a $\log ^{10}$ transformation to balance extreme values. (Rectprocal and square root transformations were found to be substantially less effective than $\log ^{10}$ in reducing heterogenelty.) (Means and standard deviations of the $\log ^{10}$ transformed data are:.represented in Appendix B.)

A test of the assumption of homogeneity of varlance again resulted in a significant violation, $F_{\max }(6,14)=30.87, \mathrm{p}<.05$. However, because the analysis of variance has been found to be relatively robust 
with respect to moderate violations of the assumption of homogeneity (Box, 1953), the $\operatorname{Iog}^{10}$ transformation was considered to have sufficient1y controlled for heterogeneity, so as to permit further analysis of the data.

The 4-way ANOVA of the transformed data resulted in a significant main effect for Factor D (daily training sessions), $F(2,84)=21.93$, $\mathrm{p}<.0001$. The ANOVA summary table for this analysis is shown in Table 1.

Insert Table 1 about here

Because no other significant main effects or interaction effects were indicated, the data were collapsed into the three levels of Factor D. A Newman-Kersis followup test (see Appendix C) was performed on the collapsed data in order to identify significant palr-wise differences across the three levels of $D$. Results indicated that responding on Day $I$ of testing was signiflcantly greater than responding on Days 2 and 3 .

Because of the higher level of responding during Day 1 of testing, a second 4-way ANOVA was perfomed. Factors A, B, and C were identical to the first analysis. However, in this case, Factor D was a 4 level factor comparing the first four 5-minute segments of the first daily testing session. Because of low rates of responding in the latter segments of the testing session, it was concluded that the 30 minute test session had been unnecessarlly lorg. Th1s is not unexpected given the durability problems historically assoclated with Sr effects and the conservative procedure employed herein for the establ 1shment of Sr 
TABLE 1

Analysis of Variance

Summary Table

Source

SS

df

MS

F

\section{Between Ss}

$\begin{array}{lrrrr}\text { A } & 1.28739 & 2 & 0.64369 & 0.87 \\ \text { B } & 0.86156 & 1 & 0.86516 & 1.17 \\ \text { A B } & 1.03150 & 2 & 0.51575 & 0.70 \\ \text { Error } & 31.16360 & 42 & 0.74199 & \end{array}$

Within Ss

\begin{tabular}{|c|c|c|c|c|}
\hline C & 0.02055 & 1 & 0.02055 & 0.14 \\
\hline$A \times C$ & 0.14037 & 2 & 0.07018 & 0.49 \\
\hline $\mathrm{B} \times \mathrm{C}$ & 0.13272 & 1 & 0.13272 & 0.92 \\
\hline$A \times B \times C$ & 0.07703 & 2 & 0.03851 & 0.27 \\
\hline Error & 6.07279 & 42 & 0.14459 & \\
\hline $\mathrm{D}$ & 7.03489 & 2 & 3.51744 & $21.93 *$ \\
\hline$A \times D$ & 0.28196 & 4 & 0.07049 & 0.44 \\
\hline$B \times D$ & 0.06729 & 2 & 0.03364 & 0.21 \\
\hline$A \times B \times D$ & 0.25577 & 4 & 0.06394 & 0.40 \\
\hline Error & 13.47117 & 84 & 0.16037 & \\
\hline$C \times D$ & 0.10700 & 2 & 0.05350 & 0.54 \\
\hline$A \times C \times D$ & 0.22538 & 4 & 0.05635 & 0.57 \\
\hline $\mathrm{B} \times \mathrm{C} \times \mathrm{D}$ & 0.16128 & 2 & 0.08064 & 0.82 \\
\hline$A \times B \times C \times D$ & 0.08797 & 4 & 0.02199 & 0.22 \\
\hline Error & 8.25744 & 84 & 0.09830 & \\
\hline
\end{tabular}

$*_{p}<.001$

A - configuration ( $6 \mathrm{sec}-5 \mathrm{sec} ; 14 \mathrm{sec}-13 \mathrm{sec} ; 14 \mathrm{sec}-5 \mathrm{sec})$

B - treatment (contiguous presentation (exp;) random presentation (cont.))

C - stimulus (stimulus 1 ; stimulus 2)

D - days (Day 1; Day. 2; Day 3) 
effects. It may be noted that Egger and M1ller using a somewhat more robust "relearning" procedure eliminated from their analysis any testing beyond the first 15 minutes for each stimulus (each having been tested separately) finding that the majority of lever presses occurred during the flrst 2-4 minutes of the test session. Because extinction was relatively complete by the end of the fourth segment as indicated by zero response rates in one of the cells of both Segments 5 and 6 , the latter were omitted from the analysis. (Appendix D includes means and standard deviatlons of the raw data for the six segments of Day 1).

As in the previous analysis, tt was necessary to perform a $\log ^{10}$ transformation on the original data In order to reduce the violation of the assumption of homogenelty to within an acceptable range $\left(F_{\max }(6,21)=\right.$ $6877.03, p<.05$ ). (Means and standard deviations of the transformed data for Segments 1 through 6 of Day 1 are represented in Appendix E.)

A test of the assumption of homogenefty of variance again indicated a slgnificant violation, $F_{\max }(6,21)=14.40, p<.05$. However, as in the previous analysis, the ANOVA was considered sufflciently robust with respect to a violation of this magnitude, to permft further data analysis. The ANOVA summary table for this analysis is shown in Table 2.

Insert Table 2 about here

A significant maln effect of Factor D (5-minute segments) was Identified, $F(3,216)=20.43, \mathrm{p}<.0001$, as well as a significant $B$ 
TABLE 2

Analysis of Variance

Summary Table

\section{Source \\ Between Ss}

SS

df

MS

F

$\begin{array}{lrrrr}\text { A } & 0.80708 & 2 & 0.4035 & 0.82 \\ \text { B } & 0.65042 & 1 & 0.65042 & 1.32 \\ \text { A B B } & 0.79049 & 2 & 0.39525 & 0.80 \\ \text { Error } & 20.63619 & 42 & 0.49134 & \end{array}$

Within Ss

$\begin{array}{llrll}\text { C } & 0.00395 & 1 & 0.00395 & 0.02 \\ \mathrm{~A} \times \mathrm{C} & 0.09828 & 2 & 0.04914 & 0.26 \\ \mathrm{~B} \times \mathrm{C} & 0.90866 & 1 & 0.90866 & 4.73 * \\ \mathrm{~A} \times \mathrm{B} \times \mathrm{C} & 0.31134 & 2 & 0.15567 & 0.81 \\ \text { Error } & 8.07419 & 42 & 0.19224 & \end{array}$

\begin{tabular}{lrrrc} 
D & 8.25173 & 3 & 2.75058 & $20.43 * *$ \\
$\mathrm{~A} \times \mathrm{D}$ & 1.00958 & 6 & 0.16826 & 1.25 \\
$\mathrm{~B} \times \mathrm{D}$ & 1.01812 & 3 & 0.33937 & 2.52 \\
$\mathrm{~A} \times \mathrm{B} \times \mathrm{D}$ & 0.51329 & 6 & 0.08555 & 0.64 \\
Error & 16.96379 & 126 & 0.13463 & \\
$\mathrm{C}$ & & & & \\
$\mathrm{A} \times \mathrm{D}$ X D & 0.20326 & 3 & 0.06775 & 0.50 \\
$\mathrm{~B} \times \mathrm{C}$ X D & 1.08329 & 6 & 0.18040 & 1.32 \\
$\mathrm{~A} \times \mathrm{B}$ X C X D & 0.32967 & 3 & 0.10989 & 0.80 \\
Error & 0.66040 & 6 & 0.11007 & 0.81 \\
\hline
\end{tabular}

\footnotetext{
${ }^{\star} \mathrm{p}<.05$

$* * \mathrm{p}<.0001$

A - configuration ( $6 \mathrm{sec}-5 \mathrm{sec} ; 14 \mathrm{sec}-13 \mathrm{sec} ; 14 \mathrm{sec}-5 \mathrm{sec}$ )

B - treatment (contiguous presentation (exp.); random presentation (cont.))

C - stimulus (stimulus 1; stimulus 2)

D - segments (Sec. 1; Seg. 2; Seg. 3; Seg. 4)
} 
(experiment al/control) by $C(S 1 / S 2)$ interaction, $F(1,42)=4.73$, p<.05, i.e., whlle responses to Stimulus 2 were roughly equivalent for both experimental and control subjects, experimentals responded less to Stimulus 1 , while controls responded more to the same stimulus. No other significant effects were indicated.

Because Factor $D$ did not significantly interact with any other factors, cells were collapsed into a one-way analysis across the four 5-minute segments of Day 1 of testing. Means and Standard Deviations for this analysis are presented in Table 3.

Insert Table 3 about here

A Newman-Keuls follow-up test (see Append1x F) performed on this data indicated that responding in both Segment 1 and Segment 2 was significantly greater than responding in Segments 3 and 4 . No other pairwise differences were indicated.

Graphs of the BC (treatment $x$ stimulus) interaction at levels of B (Éreatment) represented in Figure 5, and at levels of C (Stimu1us) represented in Figure 6 indicated that simple main effects tests were necessary for both $B$ at each level of $C$, and $C$ at each level of B. The required BC (treatment $x$ stimulus) sumary table for the data from the second ANOVA is presented in Table 5. 


\section{TABLE 3}

Means and Standard Deviations for

Number of Lever Presses Collapsed

Across All Factors for Segments 1,2 ,

3 , and 4 of Day 1 of Testing

\begin{tabular}{crrrr}
\hline Segment & 1 & 2 & 3 & 4 \\
\hline $\bar{X}$ & 6.77 & 7.02 & 5.28 & 3.17 \\
SD & 7.98 & 18.64 & 19.36 & 7.77 \\
\hline
\end{tabular}


Figure Caption

Figure 5. Graph of BC (treatment $x$ stimulus) interaction at levels of B (treatment) across all subjects for Segments 1, 2, 3, and 4 of Day 1 of testing. 


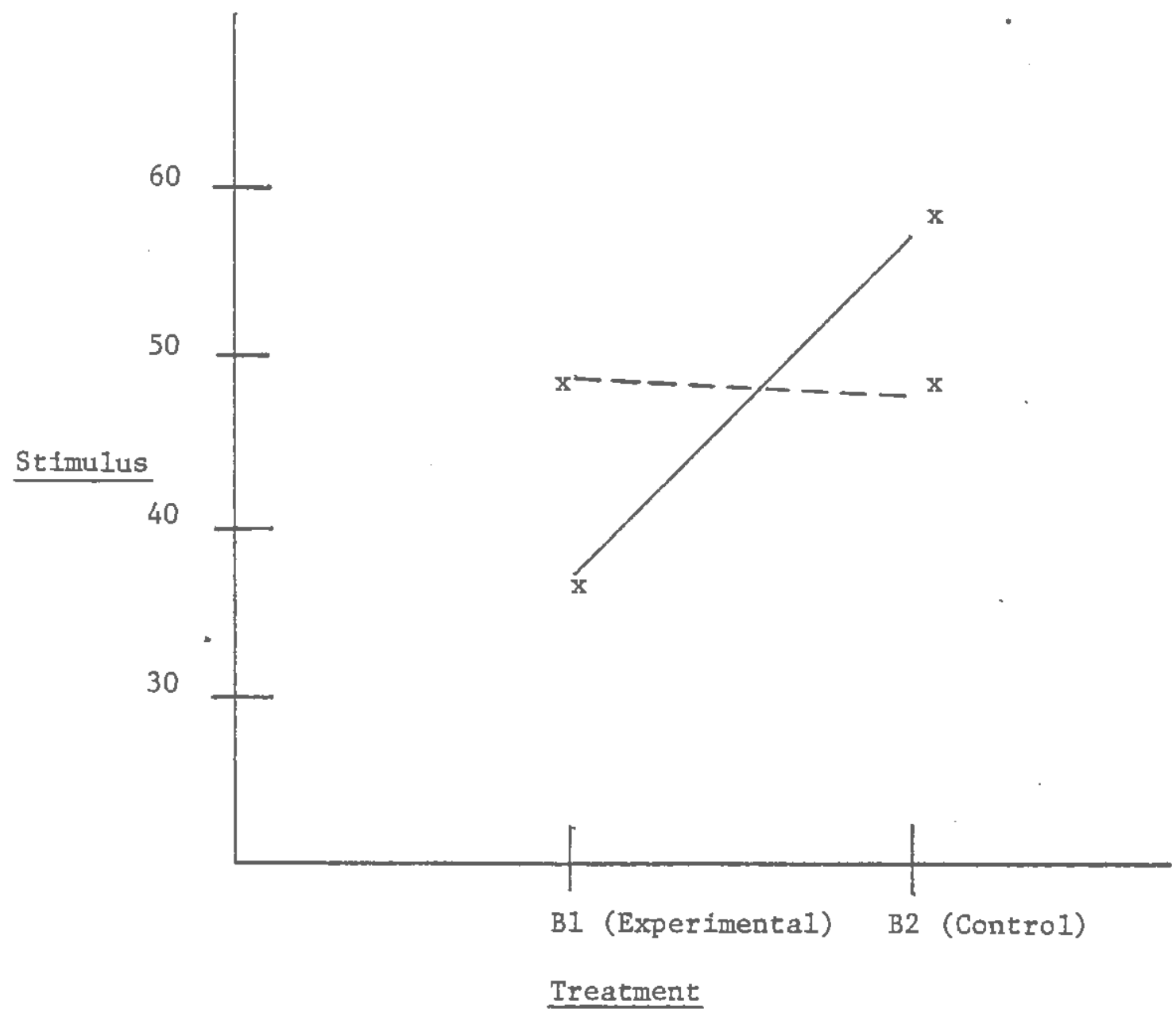

$\mathrm{x}$ - $\mathrm{x}$ Stimulus 1 (CI)

x----ax Stimulus 2 (C2)

FIgure 5 
Insert Figure 6 about here

Insert Table 4 about here

A test of B ('treatment) at $C_{1}$ (stimulus 1) (see Appendix G) indicated that control subjects responded significantly more often than experimental subjects to the lever which produced $S_{1}, F(1,84) \Rightarrow$ $55.01, \mathrm{p}<.001$. No differences were found for levels of B ('treatment) at $C_{2}$ (stimulus 2)

A test of $C$ (stimulus) at $B_{1}$ (experimenta1) (see Appendix $H$ ) indicated that experimental subjects responded more to $S_{2}$ than to $S_{1}$, $F(1,126)=28.15, p<.001$. In contrast, a test of $C$ (stimulus) at $\mathrm{B}_{2}$ (contro1) Indicated that control subjects responded significantly more often to obtain $s_{1}$ and $s_{2}, F(1,12 \dot{6})=11.81, p<.001$.

A prlori simple, simple main effects tests (see Appendix I) together with appropriate follow-ups were performed on C (st1mulus) at $A_{1} B_{1}\left(6 \mathrm{sec}-5 \mathrm{sec} x\right.$ experimental), $C$ (stimulus) at $A_{2} B_{1}$ (14 sec $13 \mathrm{sec} x$ experimenta1), and $C$ (stimulus) at $A_{3} B_{1}(14 \mathrm{sec}-5 \sec x$ experfmenta1) in order to test predictions outined in the introduction. The required $A B C$ (e onfiguration $x$ treatment $x$ stimulus) summary tables are presented in Table 5. 


\section{Figure Caption}

Figure 6. Graph of BC (treatment X stimulus) Interaction at levels of C (stimulus) across all subjects for Segments 1, 2, 3, and 4 of Day 1 of testing. 
45.

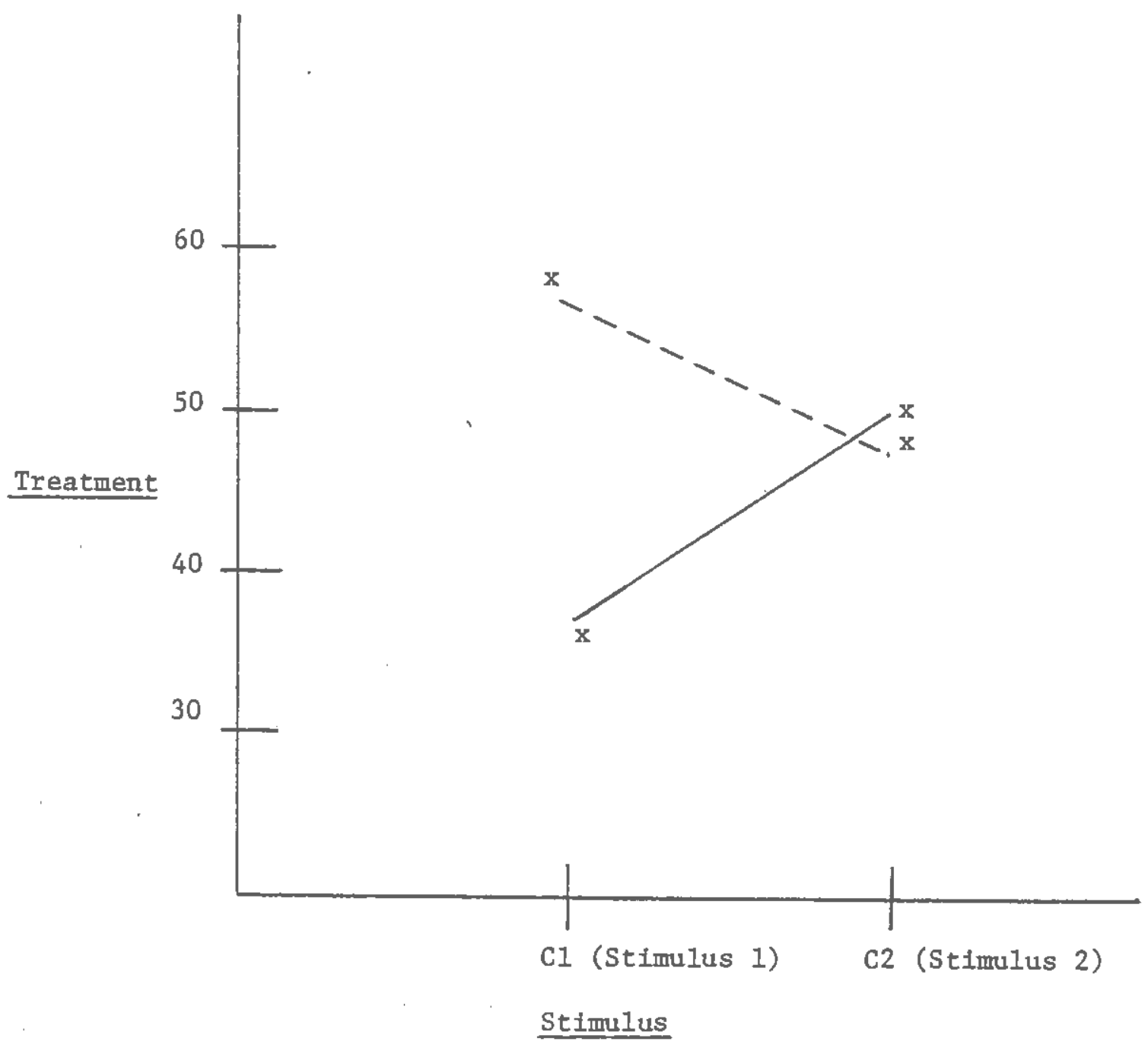

$\mathrm{x}$ Experimental Ss (B1)

$\mathrm{x} \cdots \mathrm{x}$ Control Ss (B2)

Figure 6 
TABLE 4

BC Summary Table:

Interaction of Treatment with Stimulus:

Day 1; Segments 1-4 of Log Transformed Scale

\begin{tabular}{cccc}
\hline & C1 (Stimulus 1) & C2 (Stimulus) & Total \\
\hline B1 (Exper1mental) & 36.20634 & 49.69326 & 85.899 \\
B2 (ControI) & 56.97976 & 48.25560 & 105.236 \\
\hline Total & 93.186 & 97.949 & 191.135 \\
\hline
\end{tabular}


TABLE 5

$$
\begin{gathered}
\text { AB Sumary Table } \\
\frac{\text { Interaction of Configuration with Treatment: }}{\text { Day } 1 ; \text { Segments 1-4 }}
\end{gathered}
$$

\section{B1 (experimenta1) B2 (control) Tota1}

\begin{tabular}{cccc} 
Al $(6 \mathrm{sec}-5 \mathrm{sec})$ & 29.7704 & 26.8441 & 56.6145 \\
$\mathrm{~A} 2(14 \mathrm{sec}-13 \mathrm{sec})$ & 29.8051 & 38.6789 & 68.4840 \\
$\mathrm{A3}(14 \mathrm{sec}-5 \mathrm{sec})$ & 29.8569 & 39.7124 & 69.5693 \\
\hline Tota1 & 89.4324 & 105.2354 & 194.6678 \\
\hline
\end{tabular}

$$
\frac{\text { Interaction of } \frac{A B C \text { Summary Table }}{\text { Configuration w1th Treatment With }}}{\text { Stimulus: Day } 1 ; \text { Segments } 1-4}
$$

$$
\text { Cl(Stimulus 1) C2(Stimulus 2) Total }
$$

\begin{tabular}{llll} 
AlB1 (6 sec-5 sec x experlemntal) & 13.9372 & 15.8332 & 29.7704 \\
AIB2(6 sec-5 sec x control) & 13.5322 & 13.3119 & 26.8441 \\
A2B1(14 sec-13 sec x experimenta1) & 11.6504 & 18.1547 & 29.8051 \\
A2B2(14 sec-13 sec x control) & 21.5750 & 17.1039 & 38.6789 \\
A3B1(14 sec-5 sec x experimenta1) & 14.1512 & 15.7057 & 29.8569 \\
A3B2(14 sec-5 sec x control) & 21.8726 & 17.8398 & 39.7124 \\
\hline & 96.7186 & 93.9492 & 190.6678
\end{tabular}


No significant differences were found between levels of $\mathrm{C}$ at $\mathrm{A}_{1} \mathrm{~B}_{1}$, or between levels of $C$ at $A_{3} B_{1}$. However, at $A_{2} B_{1}$, experimental subjects responded more to obtain $S_{2}$ than to obtain $S_{1}, F(1,126)=19.64$, $\mathrm{p}<.001$

As a follow-up to the 1dentification of this significant effect, a test of $\mathrm{C}$ (stimulus) at $\mathrm{A}_{2} \mathrm{~B}_{2}(14 \mathrm{sec}-13 \mathrm{sec} \mathrm{x}$ contro1) was performed. Results indicated that control subjects responded more to receive $\mathrm{S}_{1}$ than $\mathrm{S}_{2}, F(1,126)=9.28, \mathrm{p}<.005$. Further, a simple main effects test of $B$ (treatment) at $A_{2}(14 \mathrm{sec}-13 \mathrm{sec})$ (see Appendix I) Indicated that control subjects responded more during the first four 5-mfnute segments of testing than did experimental subjects, $F(1,42)=$ $5.01, \mathrm{p}^{<.05}$

In order to statistically examine the possibility of a preference for one stimulus modality over the other, a dependent $t$-test was performed on overa11 responses to the tone versus the flashing 1 Ight. No signiflcant differences were found. However a dependent t-test of a position preference for the right versus left lever, indicated a right position preference, $t(47)=2.02, p<.05$, underlining the importance of the experimental counterbalancing of this factor. 


\section{DISCUSSION}

Results of the 4-way ANOVA with repeated measures across days of testing indicate that the testing procedure provided an opportunity for responding well beyond that necessitated by the training procedure. As indicated by a slgnificant main effect across days of testing, responding was concentrated in the first 30-minute testing session (Day 1) with negligible responding occurring during testing on Days 2 and 3 .

An examination of means and standard deviations across consecutIve 5-minute testing periods on Day I indicates that extinction had occurred in some cells for the most part by the end of the fourth 5minute session as Indicated by means and standard deviations of 0 for cells in Segments 5 and 6 . An a posteriorl analysis would therefore Indicate that, given these experimental training conditions, the more approprlate length of testing would approximate 20 minutes. This is not surprising glven the use of the relatively conservative "new learning" parad1gm which has shown 1 prior studies that, as new learning occurs, the $S^{r}$ effect is simultaneously extinguishing.

Given the conclusion that extinction was complete in some cells at the end of the first 20 minutes of testing on Day 1, only Segments 1 through 4 were 1ncluded in the second 4-way ANOVA. Results indicate that responding across all subjects was greatest in Segments 1 and 2, thereafter diminishing across Segments 3 and 4 . 
Of the three a-priori predictions regarding the establishment of $S^{r}$ effects, none were confirmed. A follow-up analysis of the significant $B C$ (treatment $x$ stimulus) interaction and of the $A B C$ (configuration $\mathrm{x}$ treatment $\mathrm{x}$ stimulus) interaction as dictated by the above-mentioned predictions, yielded largely equivocal results. Control subjects responded more to the first stimulus in the stimulus pair than did experimental subjects. It is possibie that a pretraining preference for $\mathrm{S}_{1}$ existed, as indicated by control subjects. Such a preference is likely to exist as a result of the functioning of a novel stimulus in the environment to which orienting responses would be directed (Sutherland, 1961). Such a preference for SI would necessarily neutralize, to some extent, the establishment of what is likely to be at best a weak preference for $\$ 2$ on the basis of cont1gulty with SR. Such an interference effect might also explain the lower levels of responding for experimental subjects as compared to controls, i.e., given an fnitial preference for the least contiguous stimulus, response suppression could occur in the process of establishIng an alternate preference, 1.e., as the ortenting response is being weakened, the subject is learning an alternate preference. The extinguishing of the orienting response together w1th the pre-asymptotic learning of the new preference would account for Iower overall responding. While th is possible to draw these explanatory inferences from the results, the position is at best speculative. The only 1dentifiable preference for 52 was indicated by experimental subjects receiving the $14 \mathrm{sec}$. S1/13 sec. S2 (A2) pairing 
during training. Of the three SIS2 pairs, this pair is considered to be the least likely to develop an S.r effect for S2 since S2 in this pair has the least optimal contiguity interval with the primary reinforcer. Neither can an information model offer an adequate explanation for this result in view of the absence of an effect among subjects receiving elther of the other two stimulus pairs.

If we assume that contiguity of $S^{r}$ and $S R$ is sufficient for a conditioned reinforcement effect, It would appear that the procedure employed, while weIl controlled, was not sufficiently sensitIve methodologically for either the reliable establishment of or measurement of an $\mathrm{Sr}$ effect. In light of the fact that the present study was designed to incorporate aspects of studies by both Bersh (I95I) and Egger and Miller (1963), both of which reported positive Sr effects, some discussion of differences between these studies and the present study is warranted.

The present study differed from Bersh's study (1) in that Bersh used a $231 / 2$ hour food deprivation schedule rather than water deprivation and (2) In that Bersh measured baseline operant levels, and equated subfects accordingly during a pretraining procedure. Similar to the present study, Bersh employed a non-response contingent pairing procedure during training (though Bersh used food pellets and their assoclated sound cues, a 10-pellet magazine training period, and 160 pairfigs). While Bersh's design did find between group effects for the ISI variable, no controls were employed nor was any analysis performed to determine the extent to which test results 
indicated an increase over baseline operant levels. It is important to note that the range of pretraining means used to equate subjects across experfmental groups was 1 fmtted to 34.8 to 35.3 . Median responses across groups for the first test session following training, where responding was greatest, ranged from 27.5 to 41.0 . It is concelvable therefore that a pre-post comparison of responses in Bersh's study would have indicated no learning effect.

While it is possible that the fallure to replicate is the result of using water rather than food deprivation, the foregoing criticisms, regarding the lack of controls and the possible equivalence of pre and post trafning responding, together with the fallure of the present study to yield an effect under simflar, but somewhat better controlled training procedures, render Bersh's results somewhat questionable.

Egger and Miller's (I963) study, on the other hand, employed a somewhat more robust training procedure than that of the present study. In contrast to the conservative new learning procedure employed in the present design, Egger and Miller employed a relearning procedure. Subjects were first pretrained over a period of 6 25-minute sessions to lever press for the SR (food pellets) on an FR 4 schedule, Trainfing was simflar to that employed by the present study. However, testing began with subjects lever pressing on an FR3 schedule for thirty presentations of the SR alone. Following the presentation of the thirtleth pellet, a 10-minute extinction period ensued after which one of the prevlously neutral stimuli was delfvered contingent upon 
lever pressing. In contrast to the preference test employed in the present study, differential responding to SI and S2 was assessed on the basis of responding for each stimulus on a single lever during consecutive test sessions, counterbalanced for order of $\mathrm{S} 1$ and $\mathrm{S} 2$ across subjects.

While Egger and Miller's results are questionable on other grounds (as indicated in the introduction), they were able to demonstrate reliable differential effects. It is possible that the procedure employed herein, while substantially less confounded than that used by Egger and Miller, was simply too conservative to yield measurable results.

In considering various aspects of the present study independentIy, one possible reason for the failure to find a reliable effect stems from the inability to measure the number of pairings actually received in contrast to the number presented. While anfmals were observed to be dipper trained and actively seeking the sucrose solution at the food cup, such observations were performed intermittently by the experimenter and were not systematically measured. Along this line, some authors (Silverstein \& Lipsitt, 1974; Keehn, 1962; Doerries, Silverstein, \& Smith, in press) have suggested that pairing must be contingent upon some instrumental response during trafning in order for an $\mathrm{Sr}$ effect to be established. It is possible, however, that it is not the operant itself which is critical but rather the fact that the operant maximizes the probability that the SrSR pair will be received by the subject. The work of Stein 
(1958) and Crowder et al. (1972) would certainly support this alternate 1nterpretation of the effect of the operant in Sr training. It is also possible that these authors (Silverstein \& Lipsitt, 1974; Keehn, 1962; Doerries, S1lverstein, \& Stith, in press) are correct in postulating the necessity of response contingent training for the establishment $\mathrm{Sr}$ effects. If this is, in fact, a requirement, the results of this study can be attributed merely to the effect of opposite stimulus novelty.

An addftional possibility is that Sr effects were established but were relatively weak and therefore below the threshold necessary for ylelding a significant effect. Doerries et al. (in press), for example, found that by varying testing to incorporate both a distributed (versus massed) procedure and a delay over time, a remarkably durable Sr effect was 1dentiflable, with subjects required to perform an operant during trainfng. This durabilfty was attributed in large part to a spontaneous recovery effect.

Finally, it is possible that a more appropriate test of Sr effects involves the use of the contiguous SIS2 pair. Some authors (Thomas, Berman, Serednesky, \& Lyons, 1968; Borgealt, Donahoe, \& Weinstein, 1972) have evidence for the effectiveness of the compound In contrast to either S1 or S2 individually. It is suggested that it is the compound which is the most contlguous with the SR and that the preference for $S 1$ over $S 2$ as found by Egger and Miller is more parsimoniously explained by the phenomenon of stimulus generalfzation decrement; that is, while S2 only occurs in compound with SI, SI 
occurs alone and therefore is less subject to stimulus generalization decrement from training to testing.

Additional research is suggested (1) which insures that the SrSR pair is received upon presentation non-contingently (as in the study by Crowder et a1,, 1972) and (2) which measures the relative effectiveness of the stimulus compound as weil as the individual stimuli. The careful investigation of these variables could offer some clariffcation of the largely equivocal results obtained in this study. 


\section{REFERENCES}

Autor, S. H. The strength of conditioned reinforcers as a function of frequency and probability of reinforcement. In D. P. Hendry (Ed.), Conditioned Reinforcement. Homewood, I11.: Dorsey Press, 1969, 127-162.

Bersh, P. J. The influence of two variables upon the establishment of a secondary reinforcer for operant responses. Journal of Experimental Psychology, 1951, 41, 62-73.

Bilbrey, J. \& Winokur, S. Conditioned reinforcement: Effects of temporal contingency and percentage of pairing. Journal of General Psychology, 1975, 93, 247-260.

Bolles, R..C. Theory of Motivation. New York: Harper \& Row, 1967. Borgea 1t, A. J., Donahoe, J. W., \& Weinstein, A. Effects of delayed and trace components of a compound CS on conditioned suppression and heart rate. Psychonomic Science, 1972, 26, 13-15. Bower, G., McLean, J., \& Meacham, J. Value of knowing when reinforcement is due. Journal of Comparative and Physlological Psychology, 1966, 62, 184-192.

Box, G. E. P. Non-normality and tests of variances. Biometrika, $1953,40,318-335$.

Bugelski, R. Extinction with and without sub-goal reinforcement. Journal of Comparative Psychology, 1938, 26, 121-133.

Crowder, W. F., Smith, S. G., Davis, W. M., Noel, J. T., \& Cousseus, W. R. Effect of morphine dose size on the conditioned reinforcer 
potency of stimuli paired with morphine. Psychological Record, 1972, 22, 441-448.

D'Amato, M. R. Secondary reinforcement and magnitude of primary reinforcement. Journal of Comparative and Physiological Psychology, 1955, 48, 378-380.

Dinsmoor, J. A. A quantitative comparison of the discriminative and relnforcing functions of a stimulus. Journal of Experimental Psychology, $1950,40,458-472$.

Doerries, L. E., Silverstein, A., \& Smith, N. F. Acquisition and retention of conditioned reinforcement as a function of variability in training setting and distribution of testing, in press.

Egger, M. D. \& Miller, N. E. Secondary reinforcement in rats as a function of information value and reliability of the stimulus. Journal of Experimental Psychology, 1962, 64, 97-104.

Ferster, C. B. Sustafned behavior under delayed reinforcement. Journal of Experimenta1 Psychology, 1953, 45, 218-224. Gilbert, T. F. \& Sturdivant, E. R. The effect of a food-associated stimulus on operant-level locomotor behavior. Journal of Comparative and Physiologica1 Psychology, 1958, 51, 255-257.

Greene, J. E. Magnitude of reward and acquisition of a black-white discrimination habit. Journal of Experimental Psychology, $1953,46,113-119$.

Guttman, N. Operant conditioning, extinction, and periodic relnforcement in relation to concentration of sucrose used as reinforcing 
agent. Journal of Experimental Psychology, 1953, 46, 213-224. Hendry, D. P. (Ed,) Conditloned Reinforcement. Homewood, Ill.:

Dorsey Press, 1969.

Eyde, T. S. The effect of Pavlovian stimuli on the acquisition of

a new response. Learning and Motivation, 1976, 7, 223-239.

Keehn, J. D. The effect of post-stimulus conditions on the secondary reinforcing power of a stimulus. Journal of Comparative and Phys1ologtcal Psychology, 1962, 55, 22-26.

Kelleher, R. T., \& Gollub, L. R. A review of positive conditioned reinforcement. Journal of Experimental Analysis of Behavior, $1962,5,543-597$.

Keller, F. S. \& Schoenfeld, W. N. Principles of Psychology. New York: Appleton-Century-Crofts, 1950.

KIing, J. W. \& Schrier, A. M. Positive reinforcement. In KIIng, J. W. \& Riggs, I. A. (Eds.) Expertmenta1 Psychology. 3rd ed. New York: Holt, Rinehart, \& Winston, 1972, 615-702. Longstreth, L. E. A cognitive interpretation of secondary reinforcement. Nebraska Sympos 1um of Motivation, 1971, 33-80. Pliskoff, S. S., Hawkins, T. D., \& Wright, J. E. Some observations of the discriminative stimulus hypothesis and rewarding electrical stimulation of the brain. Psychological Record, $1964,14,179-184$

Ratner, S. C. Effect of extinction of dipper approaching on subsequent extfnction of bar-pressing and dipper-approaching. Journal of Comparative and Physiological Psychology, 1956, 49, 576-581. 
Rescorla, R. A. Pavlovian conditioning and its proper control procedures. Psychological Review, 1967, 74, 71-80. Saltzman, I. J. Maze learning in the absence of primary reinforcement: A study of secondary reinforcement. Journal of Comparative and Physiologica1 Psychology, 1949, 12, 161-173. Shoenfeld, W. N., Antonitis, J. J., \& Bersh, P. J. A preliminary study of training conditions necessary for secondary reinforcement. Journal of Experimental Psychology, 1950, 40, $40-45$.

Silverstein, A. \& Lipsitt, L. P. The role of 1nstrumental responding and contigutty of stimuli in the development of infant secondary relnforcement. Journal of Experimental Chfld Psychology, 1974, 17, 322-221.

Skinner, B. F. The Behavior of Organisms. New York: AppletonCentury-Crofts, 1938.

Stein, L. Secondary rejnforcement established with subcortical stimulation. Sclence, 1958, 127, 466-467.

Sutherland, N. S. V1sual discrimination of horlzontal and vertical rectangles by rats on a new discrimfnation tralning apparatus. Quarter1y Journal of Experimenta1 Psychology, 1961, 13, 117-121. Thomas, D. R., Berman, D. L., Serednesky, G. E., \& Lyons, J. Information value and stimulus configuring as factors in conditioned reinforcement. Journal of Experimental Psychology, $1968, .76,181-189$. 
Wike, E. L. Secondary Reinforcement. New York: Harper \& Row, 1966.

Wolfe, J. B. Effectiveress of token rewards for chimpanzees. Comparative Psychology Monographs, 1936, 12, 1-72. Wyckoff, L. B. The role of observing responses in discrimination learning. In D. P. Hendry (Ed.) Conditioned Reinforcement. Homewood, I11.: Dorsey Press, 1969, 237-260. 


\section{APPENDIX A}

Means and Standard Deviations for Number of Lever Presses During Testing.

Part I. $D_{1}$ (Day I; 30 Minute Session)

$A_{1}\left(S_{1}, 6\right.$ seconds; $S_{2}, 5$ seconds $)$

$B_{1}$ (Experimental) $B_{2}$ (Control)

$\begin{array}{lrrr}C_{1} \text { (Stimulus 1) } \bar{x} & 14.37 & 12.62 \\ & \text { SD } & 11.41 & 8.24 \\ C_{2} \text { (Stimulus 2) } \bar{X} & & 20.87 & 39.62 \\ & \text { SD } & . .22 .54 & 87.57\end{array}$

$A_{2}\left(S_{1}, 14\right.$ seconds; $S_{2}, 13$ seconds)

$\mathrm{B}_{1}$ (Experimental) $\mathrm{B}_{2}$ (Control)

$\begin{array}{lrrr}C_{1} \text { (Stimulus 1) } & \overline{\mathrm{X}} & 21.75 & 67.87 \\ & \mathrm{SD} & 31.83 & 125.88 \\ \mathrm{C}_{2} \text { (Stimulus 2) } & \overline{\mathrm{X}} & & \\ & \text { SD } & 22.87 & 26.25 \\ & & 23.54 & 19.28\end{array}$

$A_{3}\left(S_{1}, 14\right.$ seconds; $s_{2}, 5$ seconds)

$\mathrm{B}_{1}$ (Experimenta1) $\mathrm{B}_{2}$ (Control)

$\begin{array}{lrrr}\mathrm{C}_{1} \text { (Stimulus 1) } & \overline{\mathrm{X}} & 15.62 & 24.37 \\ & \mathrm{SD} & 8.50 & 8.26 \\ \mathrm{C}_{2} \text { (Stimulus 2) } & \overline{\mathrm{X}} & 20.00 & \\ & \mathrm{SD} & 21.51 & 18.50 \\ & & & 13.68\end{array}$


APPENDIX A

Means and Standard Deviations for Number of

Lever Presses During Testing

Part II. $\mathrm{D}_{2}$ (Day 2; 30 Minute Session)

$A_{1}\left(S_{1}, 6\right.$ seconds; $S_{2}, 5$ seconds)

$B_{1}$ (Experimenta1) $\quad B_{2}$ (Contro1)

$\begin{array}{lrrr}C_{1} \text { (Stimulus 1) } & \overline{\mathrm{X}} & 12.37 & 17.00 \\ & \mathrm{SD} & 10.74 & 24.43 \\ & & & \\ \mathrm{C}_{2} \text { (Stimulus 2) } & \overrightarrow{\mathrm{X}} & 15.50 & 7.25 \\ & \mathrm{SD} & 25.50 & 6.86\end{array}$

$A_{2}\left(S_{1}, 14\right.$ seconds; $S_{2}, 13$ seconds)

$\mathrm{B}_{1}$ (Experimental) $\mathrm{B}_{2}$ (Control)

$\begin{array}{lrrr}\mathrm{C}_{1} \text { (Stimulus 1) } & \overline{\mathrm{X}} & 9.37 & 20.37 \\ & \mathrm{SD} & 13.90 & 32.70 \\ \mathrm{C}_{2} \text { (Stimulus 2) } & \overline{\mathrm{X}} & 6.62 & 20.25 \\ & \mathrm{SD} & 6.32 & 31.17\end{array}$

$A_{3},\left(S_{1}, 14\right.$ seconds; $S_{2}, 5$ seconds $)$

$\mathrm{B}_{1}$ (Experimental) $\quad \mathrm{B}_{2}$ (Control)

$\begin{array}{lrll}\mathrm{C}_{1} \text { (Stimulus 1) } & \overline{\mathrm{X}} & 13.87 & 17.87 \\ & \mathrm{SD} & 14.33 & 23.87 \\ \mathrm{C}_{2} \text { (Stimulus 2) } & \overline{\mathrm{X}} & 12.87 & 18.37 \\ & \mathrm{SD} & 11.76 & 23.20\end{array}$


APPENDIX A

Means and Standard Deviations for Number of

Lever Presses During Testing

Part III. $\mathrm{D}_{3}$ (Day 3; 30 minute session)

$A_{1}\left(S_{1}, 6\right.$ seconds; $S_{2}, 5$ seconds $)$

$B_{1}$ (Experimental) $\quad B_{2}$ (Control)

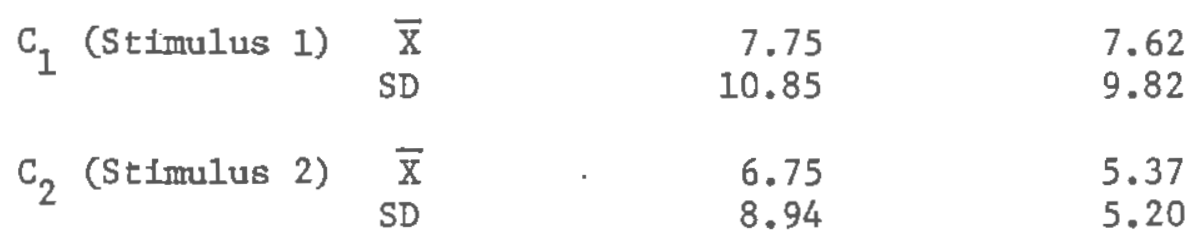

$A_{2}\left(S_{1}, 14\right.$ seconds; $S_{2}, 13$ seconds $)$

$B_{1}$ (Experimental) $B_{2}$ (Contro1)

$\begin{array}{lrrr}C_{1} \text { (Stimulus 1) } & \overline{\mathrm{x}} & 8.25 & 19.37 \\ & \mathrm{SD} & 11.33 & 30.32 \\ \mathrm{C}_{2} \text { (Stimulus 2) } & \overline{\mathrm{X}} & 8.00 & \\ & \text { SD } & 6.32 & 14.37 \\ & & & 14.27\end{array}$

$A_{3}\left(S_{1}, 14\right.$ seconds; $S_{2}, 5$ seconds $)$

$\mathrm{B}_{1}$ (Experimental) $\mathrm{B}_{2}$ (Contro1)

\begin{tabular}{lrrr}
$C_{1}$ (Stimulus 1) & $\bar{X}$ & 12.00 & 16.37 \\
& SD & 19.36 & 22.28 \\
$C_{2}$ (Stimulus 2) & $\bar{X}$ & 7.37 & 8.37 \\
& SD & 5.04 & 14.92 \\
\hline
\end{tabular}




\section{APPENDIX B}

Means and Standard Deviations of Log Transformed Scale For Number of Lever Presses During Testing

Part I. D1 (Day I; 30 minute sessions)

Al (S1, 6 seconds; S2, 5 seconds)

\section{B1 (Experimenta1) B2 (Control)}

$\begin{array}{lrll}C 1 \text { (Stimulus 1) } \bar{X} & 1.04 & 1.00 \\ & \text { SD } & 0.39 & 0.45\end{array}$

$\begin{array}{lrll}\text { C2 (Stimulus 1) } & \overline{\mathrm{X}} & 1.12 & 1.10 \\ & \mathrm{SD} & 0.48 & 0.58\end{array}$

A2 (S1, 14 seconds; S2, 13 seconds)

B1 (Experimental) B2 (Control)

$\begin{array}{lrll}\text { CI (Stimulus 1) } & \overline{\mathrm{X}} & 0.90 & 1.35 \\ & \mathrm{SD} & 0.72 & 0.67\end{array}$

$\begin{array}{lrll}\text { C2 (Stimulus 2) } & \overline{\mathrm{X}} & 1.15 & 1.35 \\ & \mathrm{SD} & 0.55 & 0.26\end{array}$

A3. (S1, 14 seconds; S2, 5 seconds)

B1 (Experimenta1) B2 (ControI)

$\begin{array}{lrll}\mathrm{Cl} \text { (Stimulus 1) } & \overline{\mathrm{X}} & 1.16 & 1.38 \\ & \mathrm{SD} & 0.23 & 0.13\end{array}$

$\begin{array}{lrll}\mathrm{C} 2 \text { (Stimulus 2) } \overline{\mathrm{X}} & 1.13 & 1.21 \\ & \mathrm{SD} & 0.45 & 0.26\end{array}$




\section{APPENDIX B}

Means and Standard Deviations of Log Transformed Scale For Number of Lever Presses During Testing

Part II. D2 (Day 2; 30 minute sessions)

A1 (S1, 6 seconds; S2, 5 seconds)

B1 (Experimental) B2 (Contro1)

$\begin{array}{lrll}\text { C1 (Stimulus 1) } & \overline{\mathrm{X}} & 0.96 & 0.84 \\ & \text { SD } & 0.42 & 0.67 \\ & \overline{\mathrm{X}} & 0.80 & \\ \text { C2 (Stimulus 2) } & \overline{\mathrm{X}} & 0.72 \\ & \text { SD } & 0.65 & 0.48\end{array}$

A2 (S1, 14 seconds; S2, 13 seconds)

B1 (Experimentai) B2 (Contro1)

$\begin{array}{lrll}\text { C1 (Stimulus 1) } & \overline{\mathrm{X}} & 0.79 & 1.02 \\ & \text { SD } & 0.43 & 0.51 \\ & & & \\ \text { C2 (Stimulus 2) } & \overline{\mathrm{X}} & 0.72 & 1.08 \\ & \text { SD } & 0.42 & 0.43\end{array}$

A3 (S1, 14 seconds; S2, 5 seconds)

B1 (Experfmental) B2 (Contro1)

$\begin{array}{lrll}\mathrm{C1} \text { (Stimulus 1) } & \overline{\mathrm{X}} & 0.98 & 1.03 \\ & \mathrm{SD} & 0.45 & 0.47 \\ \mathrm{C} 2 \text { (St1mulus 2) } & \overline{\mathrm{X}} & 0.98 & 1.00 \\ & \mathrm{SD} & 0.40 & 0.58\end{array}$




\section{APPENDIX B}

Means and Standard Deviations of Log Transformed Scale For Number of Lever Presses During Testing

Part III. D3 (Day 3; 30 minute sessions)

Al (S1, 6 seconds; S2; 5 seconds)

B1 (Experimenta1) B2 (Contro1)

$\begin{array}{lrll}\text { C1 (Stimulus 1) } & \overline{\mathrm{X}} & 0.63 & 0.76 \\ & \mathrm{SD} & 0.58 & 0.37 \\ & & & \\ \mathrm{C} 2 \text { (Stimu1us 2) } & \overline{\mathrm{X}} & 0.61 & 0.68 \\ & \text { SD } & 0.54 & 0.34\end{array}$

A2 (S1, 14 seconds; S2, 13 seconds)

B1 (Experimental) B2 (Control)

$\begin{array}{lrll}\text { Cl (Stimulus 1) } & \bar{x} & 0.73 & 1.01 \\ & \text { SD } & 0.47 & 0.48\end{array}$

$\begin{array}{lrll}\text { C2 (Stimulus 2) } & \bar{X} & 0.83 & 0.94 \\ & \text { SD } & 0.37 & 0.52\end{array}$

A3 (S1, 14 seconds; S2, 5 seconds)

B1 (Experimental) B2 (Control)

$\begin{array}{lrll}\text { C1 (Stimulus 1) } & \overline{\mathrm{X}} & 0.74 & 0.92 \\ & \mathrm{SD} & 0.59 & 0.55 \\ & & & \\ \mathrm{C2} \text { (Stimulus 2) } & \overline{\mathrm{X}} & 0.83 & 0.70 \\ & \text { SD } & 0.30 & 0.43\end{array}$


APPENDIX C

Newman-Keuls Test of Days 1, 2, and 3 Across all Subjects

$\begin{array}{rcc}\begin{array}{c}\text { D3. } \\ \text { Day 3 }\end{array} & \begin{array}{c}\text { D2 } \\ \text { Day 2 } \\ 0.76\end{array} & \begin{array}{c}\text { Day } 1 \\ 1.16\end{array} \\ 0.91 & 0.14 & 0.39 * \\ & 0.24 * \star\end{array}$

* $p^{<.01 ;}$ df $(3,42)$

** $p<.01$; df $(2.42)$ 
68.

\author{
APPENDIX D \\ Means and Standard Deviations for Number of \\ Lever Presses During Day 1 of Testing \\ Part I. D1 (Segment I; 5 minutes)
}

SI (S1, 6 seconds; S2, 5 seconds)

B1 (Experimental) B2 (Contro1)

$\begin{array}{lrll}\text { CI (Stimulus 1) } & \bar{X} & 4.50 & 4.25 \\ & \text { SD } & 5.70 & 2.81 \\ & & & \\ \text { C2 (Stimulus 2) } & \bar{X} & 7.25 & 2.12 \\ & \text { SD } & 9.43 & 2.47\end{array}$

A2 (S1, 14 seconds; S2, 13 seconds)

B1 (Experimental) B2 (Contro1)

$\begin{array}{lrrr}\text { C1 (Stimulus 1) } & \overline{\mathrm{X}} & 11.37 & 5.12 \\ & \mathrm{SD} & 18.67 & 4.79 \\ & & & \\ \mathrm{C2} \text { (Stimulus 2) } & \overline{\mathrm{X}} & 8.37 & 6.50 \\ & \text { SD } & 8.89 & 5.31\end{array}$

A3 (S1, 14 seconds; S2, 5 seconds)

B1 (Experimental) B2 (Contro1)

$\begin{array}{lrll}\text { C1 (Stimulus 1) } & \overline{\mathrm{X}} & 8.00 & 9.87 \\ & \text { SD } & 6.61 & 4.58 \\ & & & \\ \text { C2 (Stimulus 2) } & \overline{\mathrm{X}} & 8.00 & 6.00 \\ & \text { SD } & 9.88 & 3.77\end{array}$


APPENDIX D

Means and Standard Deviations for Number of Lever Presses During Day 1 of Testing

Part II. D2 (Segment 2; 5 minutes)

Al (S1, 6 seconds; S2, 5 seconds)

\section{B1 (Experimental) B2 (Control)}

$\begin{array}{lrrr}\text { G (Stimulus 1) } & \overline{\mathrm{X}} & 3.25 & 5.62 \\ & \text { SD } & 2.76 & 4.86 \\ & & & \\ \text { C2 (Stimulus 2) } & \bar{X} & 4.37 & 5.87 \\ & \text { SD } & 5.23 & 8.96\end{array}$

A2 (S1, 14 seconds; S2, 13 seconds)

B1 (Experimenta1) B2 (Control)

$\begin{array}{lrrr}\text { C1 (Stimulus 1) } & \overline{\mathrm{X}} & 5.87 & 26.87 \\ & \mathrm{SD} & 10.02 & 56.16 \\ & \overline{\mathrm{X}} & 6.12 & 3.62 \\ \mathrm{C2} \text { (Stimulus 2) } & \mathrm{S} & 8.21 & 2.77\end{array}$

A3 (S1, 14 seconds; S2, 5 seconds)

B1 (Experimental) B2 (Control)

$\begin{array}{lrll}\text { C1 (Stimulus 1) } & \overline{\mathrm{X}} & 2.37 & 4.12 \\ & \mathrm{SD} & 2.50 & 2.90 \\ & & & \\ \mathrm{C} 2 \text { (Stimulus 2) } & \overline{\mathrm{X}} & 3.62 & 3.75 \\ & \mathrm{SD} & 4.24 & 2.71\end{array}$




\section{APPENDIX D}

Means and Standard Deviations for Number of Lever Presses During Day 1 of Testing

Part III. D3 (Segment 3; 5 minutes)

AI (S1, 6 seconds; $S 2,5$ seconds)

B1 (Experimental) B2 (Control)

$\begin{array}{lrrr}\text { C1 (Stimulus 1) } & \overline{\mathrm{X}} & 0.87 & 1.25 \\ & \mathrm{SD} & 1.45 & 1.28 \\ & \overline{\mathrm{X}} & 4.75 & 10.37 \\ \mathrm{C} 2 \text { (Stimulus 2) } & \mathrm{S} & 8.15 & 22.23 \\ & \text { SD } & & \end{array}$

A2 (S1, 14 seconds; S2, 13 seconds)

B1 (Experimental) B2 (Contro1)

\begin{tabular}{lrrr} 
C1 (Stimulus 1) & $\overline{\mathrm{X}}$ & 0.50 & 24.37 \\
& SD & 1.41 & 61.70 \\
$\mathrm{C2}$ (StImulus 2) & $\overline{\mathrm{X}}$ & 2.75 & 5.12 \\
& SD & 3.24 & 11.72 \\
\hline
\end{tabular}

A3 (S1, 14 seconds; S2, 5 seconds)

B1 (Experimental) B2 (Contro1)

$\begin{array}{lrll}\mathrm{Cl} \text { (Stimulus 1) } & \overline{\mathrm{X}} & 2.00 & 6.25 \\ & \mathrm{SD} & 3.16 & 4.52 \\ \mathrm{C2} \text { (Stimulus 2) } & \overline{\mathrm{X}} & 1.62 & 3.50 \\ & \mathrm{SD} & 1.68 & 5.39\end{array}$




$$
\begin{gathered}
\text { APPENDIX D } \\
\frac{\text { Means and Standard Deviations for Number of }}{\text { Lever Presses During Day } 1 \text { of Testing }} \\
\text { Part IV. D4 (Segment } 4 ; 5 \text { minutes) }
\end{gathered}
$$

Al (S1, 6 seconds; S2, 5 seconds)

B1 (Experimenta1) B2 (Control)

$\begin{array}{lrll}\text { Cl (Stimulus 1) } & \overline{\mathrm{X}} & 5.25 & 0.37 \\ & \mathrm{SD} & 7.94 & 0.74 \\ & & & \\ \mathrm{C} 2 \text { (Stimulus 2) } & \overline{\mathrm{X}} & 3.62 & 0.50 \\ & \text { SD } & 8.29 & 0.75\end{array}$

A2 (S1, 14 seconds; S2, 13 seconds)

B1 (Experimental) B2 (Control)

$\begin{array}{lrrr}\text { C1 (Stimulus 1) } & \overline{\mathrm{X}} & 1.12 & 7.37 \\ & \mathrm{SD} & 2.79 & 16.21 \\ & & & \\ \mathrm{C2} \text { (Stimulus 2) } & \overline{\mathrm{X}} & 1.87 & 5.75 \\ & \text { SD } & 1.45 & 12.03\end{array}$

A3 (S1, 14 seconds; S2, 5 seconds)

B1 (Experimental) B2 (Control)

$\begin{array}{lrrr}\text { C1 (Stimulus 1) } & \bar{X} & 1.37 & 1.50 \\ & \text { SD } & 1.68 & 1.51 \\ & & & \\ \text { C2 (Stimulus 2) } & \bar{X} & 5.25 & 4.00 \\ & \text { SD } & 12.45 & 6.96\end{array}$




\section{APPENDIX D}

Means and Standard Deviations for Number of Lever Presses During Day 1 of Testing

Part V. D5 (Segment $5 ; 5$ minutes)

Al (S1, 6 seconds; $S 2,5$ seconds)

B1 (Experimental) B2 (Control)

C1 (Stimulus 1 ) $\overline{\mathrm{X}}$

0.50

0.92

0.37

$\mathrm{SD}$

0.00

0.51

C2 (Stimulus 2) $\quad \overline{\mathrm{X}}$

0.00

18.50

49.92

A2 (SI, 14 seconds; S2, 13 seconds)

B1 (Experimental) B2 (Control)

$\begin{array}{lrll}\mathrm{C1} \text { (Stimulus 1) } & \overline{\mathrm{X}} & 2.12 & 3.00 \\ & \mathrm{SD} & 4.51 & 6.16 \\ & & & \\ \mathrm{C} 2 \text { (Stimulus 2) } & \overline{\mathrm{X}} & 2.75 & 3.00 \\ & \mathrm{SD} & 3.99 & 3.96\end{array}$

A3 (S1, I4 seconds; S2, 5 seconds)

B1 (Experimental) B2 (Control)

$\begin{array}{lrll}\text { C1 (Stimulus 1) } & \bar{X} & 1.25 & 1.37 \\ & \text { SD } & 1.38 & 2.13 \\ & & & \\ \text { C2 (Stimulus 2) } & \bar{X} & 1.12 & 0.37 \\ & \text { SD } & 1.35 & 0.74\end{array}$


APPENDIX D

Means and Standard Deviations for Number of Lever Presses During Day 1 of Testing

Part VI. D6 (Segment 6; 5 minutes)

A1 (S1, 6 seconds; $S 2,5$ seconds)

B1 (Experimental) B2 (Control)

$\begin{array}{lrll}\text { C1 (Stimulus 1) } & \bar{X} & 0.00 & 0.75 \\ & \text { SD } & 0.00 & 1.75 \\ & & & \\ \text { C2 (Stimulus 2) } & \bar{X} & 0.87 & 2.25 \\ & \text { SD } & 2.47 & 5.25\end{array}$

A2 (S1, 14 seconds; S2, 13 seconds)

B1 (ExperimentaI) B2 (Control)

$\begin{array}{lrll}\text { C1 (Stimulus 1) } & \overline{\mathrm{X}} & 0.75 & 1.25 \\ & \mathrm{SD} & 1.48 & 1.83 \\ & & & \\ \mathrm{C2} \text { (Stimulus 2) } & \overline{\mathrm{X}} & 1.00 & 2.25 \\ & \mathrm{SD} & 1.77 & 3.41\end{array}$

A3 (S1, 14 seconds; S2, 5 seconds)

B1 (Experimental) B2 (Control)

$\begin{array}{lrll}\text { C1 (Stimulus 1) } & \overline{\mathrm{X}} & 0.75 & 1.25 \\ & \text { SD } & 1.16 & 1.75 \\ & & & \\ \mathrm{C} 2 \text { (Stimulus 2) } & \overline{\mathrm{X}} & 0.37 & 0.87 \\ & \text { SD } & 0.74 & 1.12\end{array}$




\section{APPENDIX E}

Means and Standard Deviations of Log Transformed Scale for Number of Lever Presses During Day 1 of Testing

Part I. D1 .(Segment 1; 5 minutes)

Al (\$1, 6 seconds; S2, 5 seconds)

B1 (Experimental) B2 (Control)

$\begin{array}{lrll}\text { C1 (Stimulus 1) } & \overline{\mathrm{X}} & 0.54 & 0.64 \\ & \text { SD } & 0.44 & 0.31 \\ \mathrm{C2} \text { (Stimulus 2) } & \overline{\mathrm{X}} & 0.62 & 0.35 \\ & \text { SD } & 0.55 & 0.38\end{array}$

A2 (S1, 14 seconds; S2, 13 seconds)

B1 (Experimental) B2 (Contro1)

$\begin{array}{lrll}\text { C1 (StimuIus 1) } & \bar{X} & 0.71 & 0.65 \\ & \text { SD } & 0.61 & 0.38 \\ & \bar{X} & 0.79 & 0.75 \\ \text { C2 (Stimulus 2) } & \bar{X} & 0.44 & 0.38\end{array}$

A3 (S1, 14 seconds; S2, 5 seconds)

B1 (Experimental) B2 (Contro1)

$\begin{array}{lrll}\mathrm{Cl} \text { (Stimulus 1) } & \overline{\mathrm{X}} & 0.77 & 0.98 \\ & \mathrm{SD} & 0.50 & 0.25 \\ \mathrm{C2} \text { (Stimulus 2) } & \overline{\mathrm{X}} & 0.72 & 0.78 \\ & \text { SD } & 0.50 & 0.23\end{array}$




\section{APPENDIX E}

Means and Standard Deviations of Log Transformed Scale for Number of Lever Presses During Day I of Testing

Part II. D2 (Segment 2; 5 minutes)

Al (SI, 6 seconds; S2, 5 seconds)

B1 (Experimental) B2 (Control)

$\begin{array}{lrll}\text { Cl (Stimulus 1) } & \bar{X} & 0.51 & 0.66 \\ & \text { SD } & 0.36 & 0.44 \\ & & & \\ \text { C2 (Stimulus 2) } & \bar{X} & 0.57 & 0.59 \\ & \text { SD } & 0.39 & 0.46\end{array}$

A2 (S1, 14 seconds; S2, 13 seconds)

BI (Experimental) B2 (Control)

$\begin{array}{lrrr}\mathrm{Cl} \text { (Stimulus 1) } & \overline{\mathrm{X}} & 0.49 & 0.90 \\ & \mathrm{SD} & 0.56 & 0.65 \\ & & & \\ \mathrm{C} 2 \text { (Stimulus 2) } & \overline{\mathrm{X}} & 0.65 & 0.57 \\ & \mathrm{SD} & 0.43 & 0.33\end{array}$

A3 (S1, 14 seconds; S2, 5 seconds)

B1 (Experimental) B2 (Control)

$\begin{array}{lrll}\text { C1 (Stimulus 1) } & \overline{\mathrm{X}} & 0.42 & 0.65 \\ & \mathrm{SD} & 0.33 & 0.24 \\ & & & \\ \mathrm{C} 2 \text { (Stimulus 2) } & \overline{\mathrm{X}} & 0.50 & 0.56 \\ & \mathrm{SD} & 0.40 & 0.37\end{array}$




\section{APPENDIX E}

Means and Standard Deviations of Log Transformed Scale for Number of Lever Presses During Day 1 of Testing

Part III. D3 (Segment 3; 5 minutes)

A1 (S1, 6 seconds; S2, 5 seconds)

B1 (ExperimentaI) B2 (Control)

$\begin{array}{lrll}\text { CI (Stimulus 1) } & \overline{\mathrm{X}} & 0.18 & 0.28 \\ & \text { SD } & 0.27 & 0.26 \\ & & & \\ \text { C2 (Stimulus 2) } & \overline{\mathrm{X}} & 0.45 & 0.58 \\ & \text { SD } & 0.53 & 0.62\end{array}$

A2 (S1, 14 seconds; S2, 13 seconds)

B1 (Experimenta1) B2 (Control)

$\begin{array}{lrrr}\text { C1 (Stimulus 1) } & \bar{X} & 0.87 & 0.68 \\ & \text { SD } & 0.24 & 0.70 \\ \text { C2 (Stimulus 2) } & \bar{X} & 0.42 & 0.38 \\ & \text { SD } & 0.39 & 0.53\end{array}$

A3 (SI, 14 seconds; S2, 5 seconds)

B1 (Experimental) B2 (Control)

$\begin{array}{lrll}\text { C1 (Stimulus 1) } & \overline{\mathrm{X}} & 0.30 & 0.77 \\ & \text { SD } & 0.39 & 0.29 \\ & \bar{X} & 0.50 & 0.56 \\ \text { C2 (Stimulus 2) } & \bar{X} & 0.27 & 0.44\end{array}$




\section{APPENDIX E}

Means and Standard Deviations of Log Transformed Scale for Number of Lever Presses During Day 1 of Testing

Part IV. D4 (Segment 4; 5 minutes)

Al ( $\mathrm{S} 1,6$ seconds; $S 2,5$ seconds)

\section{B1 (Experimental) B2 (Control)}

$\begin{array}{lrll}\text { C1 (Stimulus 1) } & \overline{\mathrm{X}} & 0.49 & 0.09 \\ & \text { SD } & 0.55 & 0.18 \\ & & & \\ \mathrm{C} 2 \text { (Stimulus 2) } & \overline{\mathrm{X}} & 0.32 & 0.13 \\ & \text { SD } & 0.48 & 0.19\end{array}$

A2 (S1, 14 seconds; S2, 13 seconds)

B1 (Experimental) B2 (Controi)

$\begin{array}{lrll}\text { C1 (Stimulus 1) } & \bar{X} & 0.15 & 0.44 \\ & \text { SD } & 0.33 & 0.61\end{array}$

$\begin{array}{lrll}C 2 \text { (Stimulus 2) } & \overline{\mathrm{X}} & 0.39 & 0.42 \\ & \text { SD } & 0.27 & 0.56\end{array}$

A3 (S1, 14 seconds; S2, 5 seconds)

B1 (Experimental) B2 (Contro1)

$\begin{array}{lrll}\text { C1 (Stimulus 1) } & \bar{X} & 0.27 & 0.31 \\ & \text { SD } & 0.31 & 0.28\end{array}$

$\begin{array}{lrll}\text { C2 (Stimulus 2) } & \overline{\mathrm{X}} & 0.39 & 0.43 \\ & \text { SD } & 0.51 & 0.46\end{array}$




\section{APPENDIX E}

Means and Standard Deviations of Log Transformed Scale for Number of Lever Presses During Day 1 of Testing

Part V. D5 (Segment $5 ; 5$ minutes)

A1 ( $S 1,6$ seconds; $S 2,5$ seconds)

B1 (Experimental) B2 (Control)

$\begin{array}{lrll}\text { C1 (Stimulus 1) } & \overline{\mathrm{X}} & 0.11 & 0.11 \\ & \text { SD } & 0.22 & 0.15 \\ & & & \\ \text { C2 (Stimulus 2) } & \overline{\mathrm{X}} & 0.0 & 0.41 \\ & \text { SD } & 0.0 & 0.75\end{array}$

A2 (S1, 14 seconds; S2, 13 seconds)

B1 (Experimental) B2 (Contro1)

$\begin{array}{lrll}C 1 \text { (Stimulus 1) } & \overline{\mathrm{X}} & 0.25 & 0.26 \\ \mathrm{SD} & 0.42 & 0.50\end{array}$

$\begin{array}{llll}\mathrm{C} 2 \text { (Stimulus 2) } \overline{\mathrm{X}} & 0.36 & 0.45\end{array}$

$\begin{array}{lll}\mathrm{SD} & 0.44 & 0.37\end{array}$

A3 (S1, 14 seconds; S2, 5 seconds)

B1 (Experimental) B2 (Control)

$\begin{array}{lrll}\mathrm{Cl} \text { (Stimulus 1) } & \overline{\mathrm{X}} & 0.26 & 0.25 \\ & \text { SD } & 0.29 & 0.32 \\ & & & \\ \mathrm{C} 2 \text { (Stimulus 2) } & \overline{\mathrm{X}} & 0.24 & 0.09 \\ & \text { SD } & 0.28 & 0.18\end{array}$




\section{APPENDIX E}

Means and Standard Deviations of Log Transformed Scale for Number of Lever Presses During Day 1 of Testing Part VI. D6 (Segment 6; 5 minutes)

Al (SI, 6 seconds; S2, 5 seconds)

\section{B1 (Experimental) B2 (Contro1)}

$\begin{array}{lrll}\text { C1 (Stimulus 1) } & \overline{\mathrm{X}} & 0.0 & 0.13 \\ & \text { SD } & 0.0 & 0.28 \\ & & & \\ \text { C2 (Stimulus 2) } & \overline{\mathrm{X}} & 0.11 & 0.22 \\ & \text { SD } & 0.31 & 0.44\end{array}$

A2 ( 1,14 seconds; S2, 13 seconds)

B1 (Experimental) B2 (Contro1)

$\begin{array}{lrll}\text { C1 (Stimulus 1) } & \overline{\mathrm{X}} & 0.14 & 0.23 \\ & \mathrm{SD} & 0.27 & 0.33 \\ & & & \\ \mathrm{C} 2 \text { (Stimulus 2) } & \overline{\mathrm{X}} & 0.19 & 0.30 \\ & \text { SD } & 0.29 & 0.43\end{array}$

A3 (S1, 14 seconds; S2, 5 seconds)

B1 (Experfmental) B2 (Contro1)

$\begin{array}{lrll}\text { C1 (Stimilus 1) } & \overline{\mathrm{X}} & 0.17 & 0.25 \\ & \mathrm{SD} & 0.25 & 0.30 \\ & & & \\ \mathrm{C} 2 \text { (Stimulus 2) } & \overline{\mathrm{X}} & 0.09 & 0.21 \\ & \mathrm{SD} & 0.18 & 0.24\end{array}$




\section{APPENDIX F}

Newman-Keuls Test of Segments 1, 2, 3 and 4 Across all Subjects

D4. D3 D2 D1

Segment 4 Segment $3 \quad$ Segment $2 \quad$ Segment 1

$\begin{array}{llll}0.32 & 0.41 & 0.59 & 0.69\end{array}$

$\begin{array}{llll}\text { D4 } & 0.87 & 0.26 * * & 0.37 * * * \\ \text { D3 } & & 0.18 * & 0.28 * * \\ \text { D2 } & & 0.10\end{array}$

${ }^{*} \mathrm{p}<.05 ; \mathrm{df}(2,126)$

$\star \star \mathrm{p}<.01 ; \mathrm{df}(3,126)$

*** $p^{<.01 ;}$ df $(4,126)$ 


\section{APPENDIX G}

Simple Main Effects Tests of B (treatient) at C (stimulus) Across all Subjects for Segments $I, 2,3$ and 4 of Day 1 of Testing

\begin{tabular}{lrrrr}
\hline Source & SS & df & MS & F \\
\hline B at CI (Stimulus 1) & 8.99 & 1 & 8.99 & $55.01 *$ \\
B at C2 (Stimulus 2) & 0.04 & 1 & 0.04 & 0.25 \\
Error & 13.73 & 84 & 0.16 & \\
\hline
\end{tabular}

$* \mathrm{p}<.001$ 
APPENDIX H

Simple Main Effects Tests of C (stimulus) at B (treatment) Across all Subjects for Segments $1,2,3$ and 4

of Day 1 of Testing

\begin{tabular}{lrrrrr}
\hline Source & SS & df & MS & F \\
\hline C at B1 (Experinental) & 3.79 & 1 & 3.79 & $28.15 *$ \\
C at B2 (Control) & 1.59 & 1 & 1.59 & $11.81^{*}$ \\
Error & 16.96 & 126 & 0.13 & \\
\hline
\end{tabular}

$* \mathrm{p}<.001$ 
Simple, Simple Main Effects Tests of C (stimulus) at AB (configuration $x$ treatment) for Segments $1,2,3$ and 4 of Day 1 of Testing

\begin{tabular}{llrrrr} 
Source & SS & df & MS & F \\
\hline C at A1B1 (6 sec-5 sec x exper) & 0.22 & 1 & 0.22 & 1.67 \\
C at A2B1 (14 sec-13 sec x exper) & 0.64 & 1 & 2.65 & $19.64 * *$ \\
$C$ at A2B2 (14 sec-13 sec x cont) & 1.24 & 1 & 1.24 & $9.28 *$ \\
C at A3B1 (14 sec-5 sec x exper) & 0.15 & 1 & 0.15 & 1.12 \\
Errot & 16.96 & 126 & 0.13 &
\end{tabular}

$* \mathrm{p}<.005$

$\star * p<.001$ 


\section{APPENDIX J}

Simple MaIn Effects Tests of B (treatment) at A2 $(14 \mathrm{sec}-13 \mathrm{sec})$ for Segments $1,2,3$ and 4 of Day 1 of Testing

\begin{tabular}{lrrrr} 
Source & SS & df & MS & F \\
\hline $\begin{array}{l}\text { B at A2 (14 sec-13 sec) } \\
\text { Error }\end{array}$ & 2.46 & 1 & 2.46 & $5.00 *$ \\
& 20.63 & 42 & 0.49 &
\end{tabular}

$$
*_{\mathrm{p}}<.05
$$

